
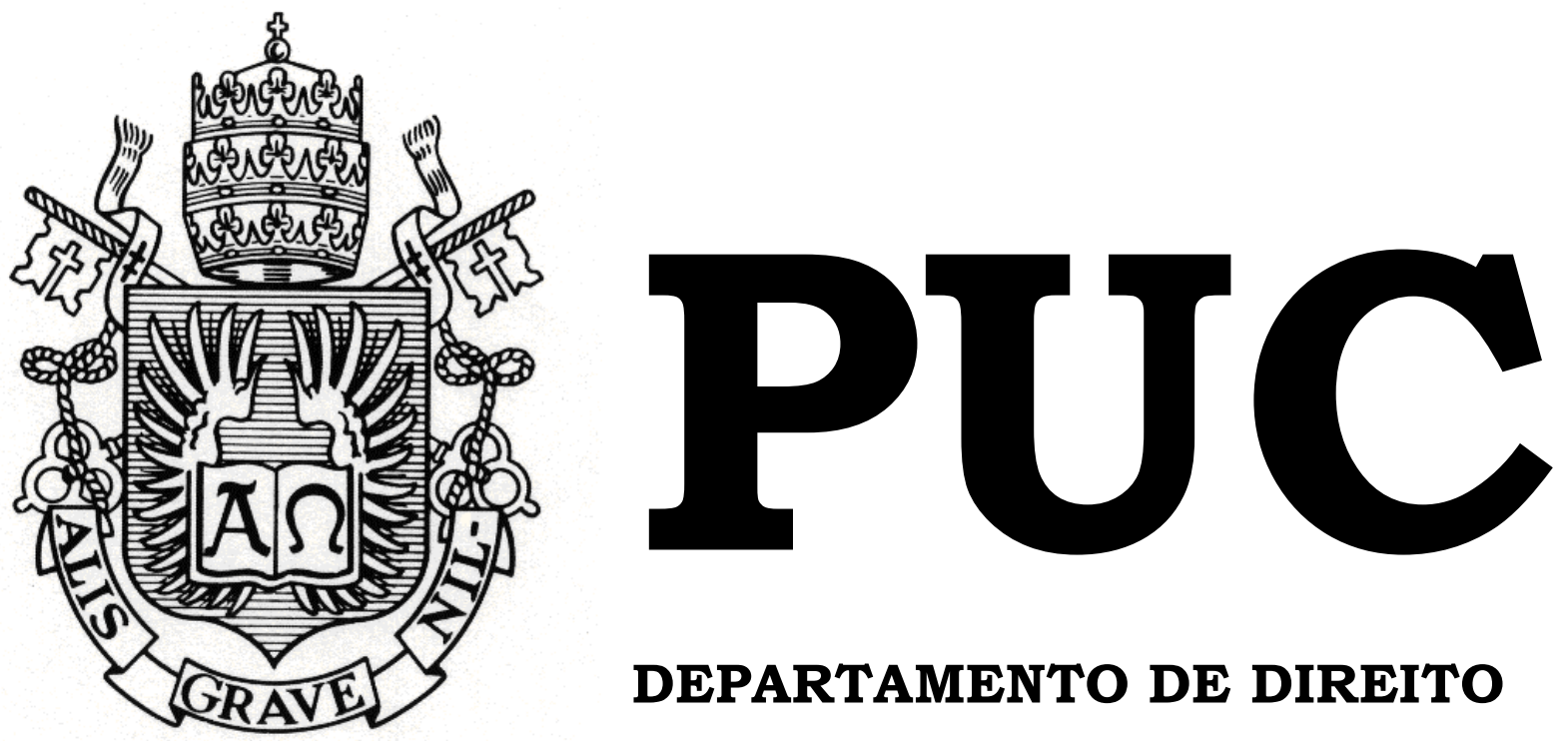

DEPARTAMENTO DE DIREITO

\title{
EFEITOS DA DECLARAÇÃO DE INCONSTITUCIONALIDADE EM AÇÕES DIRETAS DE CONTROLE
}

por

ALESSANDRA MENDES LEAL AIRES

ORIENTADOR(A): Regina Coeli Lisbôa Soares

2014.2

PONTIFÍCIA UNIVERSIDADE CATÓLICA

$$
\text { DO RIO DE JANEIRO }
$$

RUA MARQUÊS DE SÃO VICENTE, 225

CEP 22453-900 - RIO DE JANEIRO - BRASIL 


\title{
EFEITOS DA DECLARAÇÃO DE INCONSTITUCIONALIDADE EM \\ AÇÕES DIRETAS DE CONTROLE
}

\author{
por
}

\section{ALESSANDRA MENDES LEAL AIRES}

Monografia apresentada ao Departamento de Direito da Pontificia Universidade Católica do Rio de Janeiro (PUC-Rio) para a obtenção do Título de Bacharel em Direito.

Orientador(a): Regina Coeli Lisbôa Soares 


\section{Agradecimentos}

Agradeço à minha querida orientadora, professora Regina Coeli Lisbôa Soares, pelos ensinamentos, solicitude e confiança.

Agradeço ao meu namorado, Renan, pelo amor, incentivo e apoio irrestrito.

Agradeço aos meus pais, Sandra e Ricardo, pois sem eles nada seria possível.

Agradeço a Deus, por todas as razões. 


\section{Resumo}

O presente trabalho visa analisar os possíveis efeitos da declaração de inconstitucionalidade em sede de ação direta do controle de constitucionalidade brasileiro. Após uma breve introdução acerca dos aspectos gerais do controle de constitucionalidade, isto é, conceito, pressupostos, objeto e parâmetro, adentraremos no fenômeno da inconstitucionalidade, abordando as diferentes espécies existentes e os planos da existência, validade e eficácia da norma declarada inconstitucional. Posteriormente, falaremos dos principais modelos de controle de constitucionalidade e de sua influência na evolução histórica do controle brasileiro, sempre com enfoque na declaração de inconstitucionalidade e seus efeitos, até chegarmos ao modelo, em vigor, da Constituição Republicana de 1988 e da Lei 9.868/99. Discorreremos brevemente sobre as principais ações diretas do controle de constitucionalidade para, enfim, alcançarmos o objeto dessa monografia, qual seja os efeitos da declaração de inconstitucionalidade na via direta, com especial destaque à modulação desses efeitos.

\section{Palavras-chave}

Controle de Constitucionalidade Brasileiro, Ações Diretas do Controle de Constitucionalidade, Controle Concentrado, Supremo Tribunal Federal, Efeitos das decisões. 


\section{Sumário}

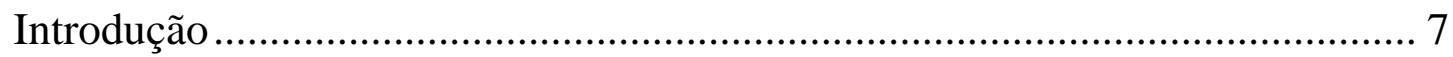

Capítulo 1 - Controle de Constitucionalidade ……................................................ 9

1.1. A Constituição e o Controle de Constitucionalidade ................................. 9

1.2. Pressupostos: a supremacia e a rigidez constitucionais ......................... 11

1.3. Objetos e parâmetro de controle ............................................................ 14

Capítulo 2 - O fenômeno da Inconstitucionalidade ............................................ 17

2.1. Espécies de Inconstitucionalidade......................................................... 17

2.1.1. Inconstitucionalidade por ação/por omissão .................................... 17

2.1.1. Inconstitucionalidade formal/material ............................................ 18

2.1.1. Inconstitucionalidade total/parcial................................................... 20

2.1.1. Inconstitucionalidade originária/superveniente.............................. 21

2.2. Os planos de existência, validade, eficácia da norma inconstitucional . 23

Capítulo 3 - Principais Modelos de Controle e suas respectivas Decisões de

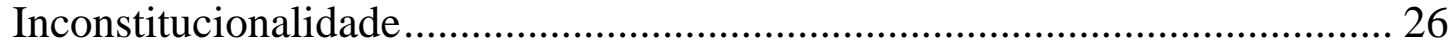

3.1. Modelo norte-americano - O Controle Judicial Difuso …………........... 26

3.2. Modelo austríaco - O Sistema de Jurisdição Concentrada....................... 29

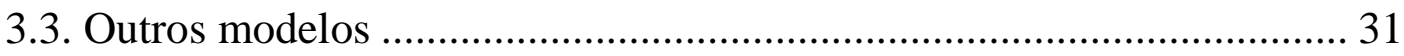

3.3.1. Modelo Francês - O Controle Político.................................................. 31

3.3.2. Modelo Português - O Sistema Misto de Controle............................. 33

3.3.3. Modelo inglês - A Ausência de Controle …………………………... 34

Capítulo 4 - Evolução do Controle de Constitucionalidade e a Fiscalização via Ação Direta no Brasil .................................................................................. 36

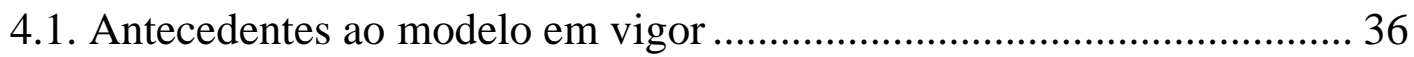




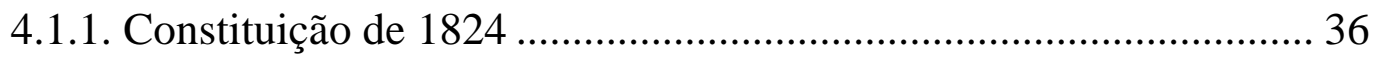

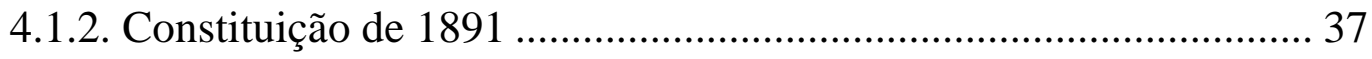

4.1.3. Constituição de 1934 ......................................................................... 39

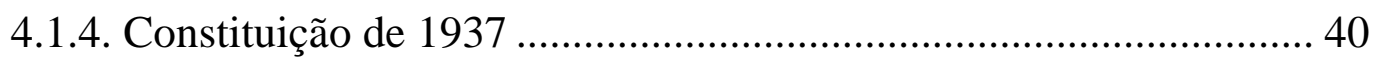

4.1.1. Constituição de 1946 ...................................................................... 41

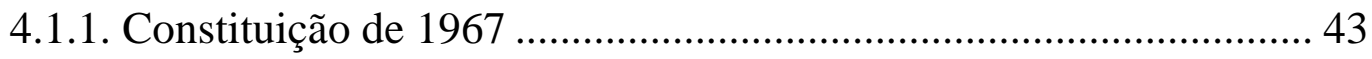

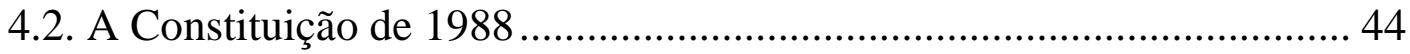

4.3. Controle de Constitucionalidade via ação direta: ADI, ADO e ADC. .. 46

4.3.1. Ação Direta de Inconstitucionalidade ............................................... 48

4.3.2. Ação Declaratória de Constitucionalidade ……………………….... 50

4.3.3. Ação Direta de Inconstitucionalidade por Omissão .......................... 51

Capítulo 5 - Efeitos da declaração de inconstitucionalidade em ações diretas do

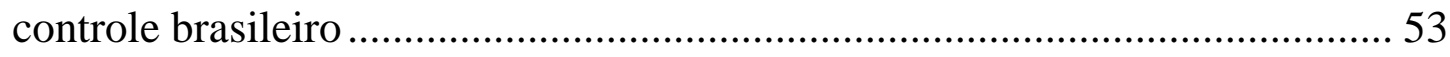

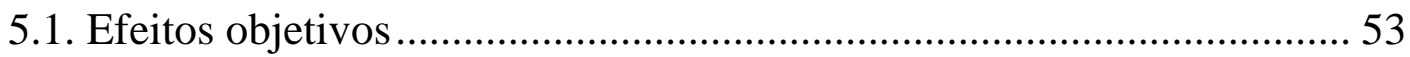

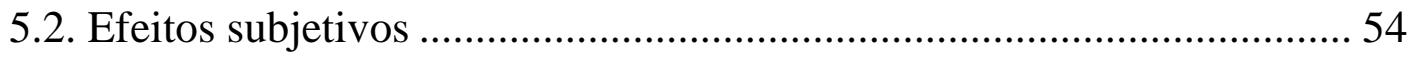

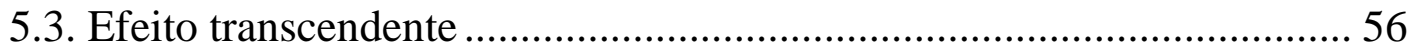

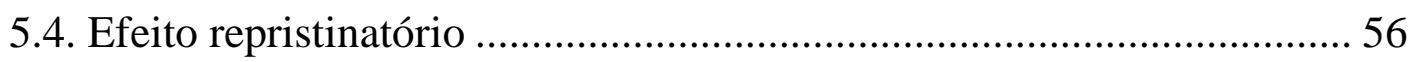

5.5. Efeitos temporais e modulação de efeitos ............................................... 57

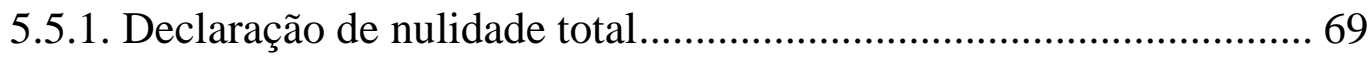

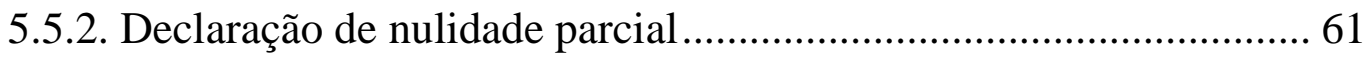

5.5.3. Declaração de nulidade parcial sem redução de texto ....................... 63

5.5.4. Interpretação conforme a Constituição................................................ 64

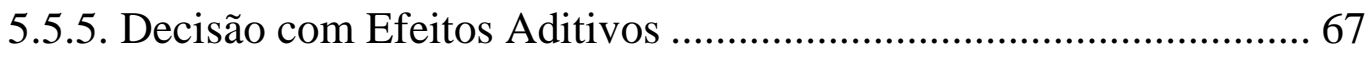

5.5.6. Declaração de Inconstitucionalidade sem a pronúncia de nulidade 68

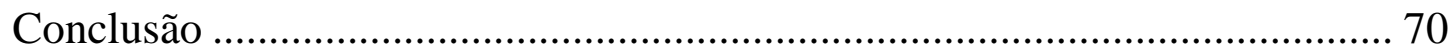

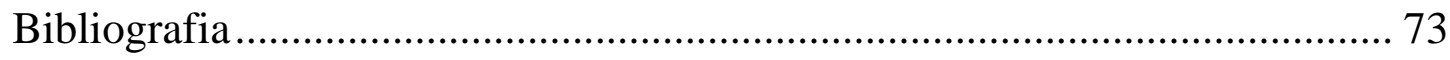




\section{Abreviaturas}

ADI - Ação Direta De Inconstitucionalidade

ADC - Ação Declaratória De Constitucionalidade

ADO - Ação Direta De Inconstitucionalidade Por Omissão

ADPF - Ação De Descumprimento De Preceito Fundamental

AGU - Advogado Geral Da União

CRFB/88 - Constituição Da República Federativa Do Brasil De 1988

EC - Emenda Constitucional

PGR - Procurador Geral Da República

STF - Supremo Tribunal Federal

STJ - Superior Tribunal De Justiça 


\section{Introdução}

O Controle de Constitucionalidade, sabe-se, é consequência e presta deferência à Supremacia da Constituição e à rigidez constitucional. Desde a antiguidade há indícios do conceito de "supremacia constitucional", mas certo é que apenas a partir de 1803, com o caso Marbury v. Madison, o controle de constitucionalidade começou a ser exercido aberta e expressamente.

Não obstante, o controle judicial de constitucionalidade só foi adotado pelo sistema jurídico brasileiro quase um século depois, em 1891, com a segunda constituição brasileira e primeira constituição republicana. Mesmo assim, na Constituição de 91, só havia previsão do controle incidental e difuso, com base no modelo americano. Apenas com a Constituição de 1934, com o surgimento da representação interventiva, que o controle concentrado de competência do STF foi introduzido.

A teoria da nulidade de leis e atos considerados inconstitucionais, do caso Marbury v. Madison, foi acolhida em quase todos os países que adotaram o controle judicial de constitucionalidade, bem como no Brasil desde o início do período republicano, com grande influência de Ruy Barbosa.

Apesar de ainda prevalecer nas decisões do controle de constitucionalidade, a teoria da nulidade perdeu força, tendo sofrido diversas mitigações sob influência do modelo de controle de constitucionalidade austríaco, de Hans Kelsen, sobretudo pela jurisprudência do Supremo Tribunal Federal e, posteriormente, pelo advento da Lei n. 9.868/99, que ampliou a competência discricionária da Suprema Corte brasileira quanto aos efeitos das decisões em controle por via direta.

O presente trabalho visa, justamente, analisar os efeitos da declaração de inconstitucionalidade em sede de ação direta, abordando efeitos subjetivos, objetivos e, sobretudo, efeitos temporais.

Analisaremos a teoria da nulidade aplicada às decisões do controle de 
constitucionalidade, mais especificamente do controle abstrato através das ações diretas, e a mitigação e flexibilização que esta teoria sofreu e continua a sofrer ao longo do tempo, como forma de harmonização da premissa da supremacia da constituição e do menor dano social possível, com fulcro na segurança jurídica e especial interesse social.

Desta forma, o primeiro capítulo introduzirá o controle de constitucionalidade, com uma breve análise de seus aspectos gerais, quais sejam o conceito, os pressupostos da supremacia e rigidez constitucionais e os objetos e parâmetros de controle.

O segundo capítulo adentrará no fenômeno da inconstitucionalidade, suas espécies e abordará os planos da existência, validade e eficácia da norma declarada inconstitucional.

O terceiro capítulo analisará os principais modelos de controle de constitucionalidade, com especial enfoque na decisão de inconstitucionalidade e seus efeitos em cada um dos modelos.

O quarto capítulo discorrerá sobre a adoção e evolução do controle de constitucionalidade no direito brasileiro, tomando por caminho as diversas constituições, novamente com especial atenção aos efeitos da declaração de inconstitucionalidade. Ainda nesse capítulo falaremos especificamente sobre a ação direta de inconstitucionalidade, a ação declaratória de constitucionalidade e a ação direta de inconstitucionalidade por omissão.

O quinto e último capítulo tratará especificamente dos efeitos subjetivos, objetivos e temporais da declaração de inconstitucionalidade em ação direta. Aqui, daremos especial atenção à teoria da nulidade e suas possíveis mitigações, conceituando-as de forma pontual e detalhada, sempre demonstrando os posicionamentos doutrinários e a evolução jurisprudencial. 


\section{Controle De Constitucionalidade}

Antes de adentrarmos no tema principal deste trabalho, qual seja os efeitos da declaração de inconstitucionalidade em ações diretas do controle de constitucionalidade, faz-se necessário abordar a priori alguns pressupostos, conceitos, origem e evolução histórica do controle de constitucionalidade, no direito externo e, sobretudo, no ordenamento jurídico brasileiro.

Esse primeiro capítulo dedica-se a tratar, brevemente, sobre o controle de constitucionalidade.

\subsection{A Constituição e o Controle de Constitucionalidade}

A Constituição de um Estado, nas palavras de José Afonso da Silva, é

"a organização dos seus elementos essenciais: um sistema de normas jurídicas escritas ou costumeiras, que regula a forma do Estado, a forma de seu governo, o modo de aquisição e o exercício do poder, o estabelecimento de seus órgãos, os limites de sua ação, os direitos fundamentais do homem e as respectivas garantias. Em síntese, a constituição é o conjunto de normas que organiza os elementos constitutivos do Estado".1

De uma forma mais simples, podemos dizer que a Constituição, tal qual seu nome indica, é o conjunto de normas que constitui uma ordem políticojurídica. A Constituição organiza e limita o poder e prevê os direitos fundamentais e garantias para aqueles que vivem sob essa ordem. É este conteúdo que afirma e justifica a supremacia da Constituição perante as demais normas do sistema jurídico.

A Constituição, chamada de "Lei Maior" não por outro motivo, é

${ }^{1}$ SILVA, José Afonso da. Curso de Direito Constitucional Positivo. 36a ed. São Paulo: Malheiros, 2013, p. 39-40. 
hierarquicamente superior a toda e qualquer outra norma do sistema. É o fundamento de validade de todas as demais normas e, sendo assim, toda lei ou ato normativo tem de estar em conformidade com o texto constitucional.

Hans Kelsen, em sua obra “Teoria Pura do Direito", diz da Constituição como Lei Fundamental. ${ }^{2}$ Explica ele que o fundamento de validade de uma norma apenas pode ser a validade de outra norma, sendo esta chamada de norma superior. Não obstante, não poderíamos nos perder no infinito, tendo de haver uma norma pressuposta como mais elevada, designada como "norma fundamental". Todas as normas que têm sua validade fundada em uma mesma norma fundamental formam uma ordem normativa, um sistema normativo. Nas palavras de Kelsen,

"É a norma fundamental que constitui a unidade de uma pluralidade de normas enquanto representa o fundamento da validade de todas as normas pertencentes a essa ordem normativa".3

Assim, o ordenamento jurídico é escalonado em diferentes níveis hierárquicos normativos e a unidade desse ordenamento se dá na medida em que há uma conexão entre as diferentes normas, que encontram seu fundamento de validade na que lhe é superior, até chegar à norma fundamental, a Constituição, o nível mais elevado.

Luís Roberto Barroso fala que o ordenamento jurídico é um sistema e, como todo sistema, "pressupõe ordem e unidade, devendo suas partes conviver de maneira harmoniosa". ${ }^{4}$ Por esse motivo e pelo Princípio Republicano ${ }^{5}$

\footnotetext{
${ }^{2}$ KELSEN, Hans. Teoria Pura do Direito. 6a ed. São Paulo: Martins Fontes, 1998, p. 215.

${ }^{3}$ Ibid. p. 217.

${ }^{4}$ BARROSO, Luís Roberto. O Controle de Constitucionalidade no Direito Brasileiro. $6^{\mathrm{a}}$ ed. rev. e atual. São Paulo: Saraiva, 2012, p. 23.

${ }^{5} \mathrm{O}$ princípio Republicano, modo pelo qual as autoridades públicas relacionam-se com seus cidadãos, impõe que a administração pública e demais representantes eleitos tenham por fim atender às aspirações do povo, cuja vontade encontra-se materializada na Constituição Republicana.
} 
presume-se a constitucionalidade das leis infraconstitucionais.

A Constituição delega o poder para que seja exercido de acordo com determinado modelo de organização, isto é, cumpre ao legislativo, executivo e judiciário atuarem em conformidade com a vontade do detentor do poder, materializada na Constituição.

Não obstante, essa presunção de constitucionalidade das leis e atos normativos é juris tantum, relativa. Caso venha a existir norma incompatível com o texto constitucional, far-se-á mister reconhecer sua invalidade e consequente ineficácia, restaurando assim a ordem do sistema. ${ }^{6}$ É essa a função primordial do controle de constitucionalidade.

O controle de constitucionalidade é o principal mecanismo de verificação da adequação de leis e atos normativos infraconstitucionais perante a Constituição. O controle de constitucionalidade é instrumento essencial para manter e devolver a unidade e harmonia que todo sistema jurídico pressupõe.

\subsection{Pressupostos do controle de constitucionalidade}

Para que haja o controle de constitucionalidade são geralmente identificadas duas premissas necessárias: a rigidez e a supremacia constitucional. $^{7}$ Apesar de este ser o entendimento majoritário doutrinário, o qual também defenderemos no presente trabalho, há outros posicionamentos.

Clèmerson Merlin Clève, por exemplo, entende que há não dois, mas três pressupostos para a fiscalização da constitucionalidade, sendo eles: (1) a existência de uma Constituição formal; (2) compreensão da constituição como lei fundamental (rigidez e supremacia constitucionais; distinção entre leis

\footnotetext{
${ }^{6}$ Ibid. p. 23-24.

${ }^{7}$ Ibid. p. 23.
} 
ordinárias e leis constitucionais); e (3) previsão de pelo menos um órgão dotado de competência para o exercício dessa atividade. ${ }^{8}$

Pedro Lenza, por sua vez, fala da rigidez e supremacia constitucionais e da atribuição de competência a um órgão como requisitos fundamentais e essenciais para o controle. ${ }^{9}$

A supremacia da Constituição, conforme debatido anteriormente, revela sua posição mais elevada na hierarquia do sistema normativo, servindo de fundamento de validade para todas as demais normas. ${ }^{10}$ Devido a essa supremacia é que nenhum ato jurídico pode subsistir se estiver em desconformidade com o texto constitucional.

A supremacia se deve por seu conteúdo único, o qual define, organiza e limita o poder delegado ao Estado e prevê os direitos fundamentais e suas garantias. Aqui, estamos falando da supremacia material, de conteúdo.

Hans Kelsen, todavia, não reconhece a supremacia material da Constituição. Ele distingue dois tipos de sistemas normativos, o estático e o dinâmico. No sistema estático, a norma fundamental fornece não só o fundamento de validade, mas também o conteúdo de validade das demais normas através de uma operação lógica. No sistema dinâmico, a norma fundamental apenas determina o modo que devem ser produzidas as demais normas. $^{11}$

Para este jurista, o direito possui caráter dinâmico e, portanto, a norma fundamental limita-se a determinar a maneira como as demais normas devem

\footnotetext{
${ }^{8}$ CLEVE, Clèmerson Merlin. A Fiscalização Abstrata da Constitucionalidade no Direito Brasileiro. São Paulo: Revista dos Tribunais, 1995, p. 23.

${ }^{9}$ LENZA, Pedro. Direito Constitucional Esquematizado. $15^{\mathrm{a}}$ ed. rev., atual. e ampl. - São Paulo: Saraiva, 2011, p. 219-220.

${ }^{10}$ BARROSO, Luís Roberto. Op. cit., p. 115.

${ }^{11}$ KELSEN, Hans. Op. cit., p. 217-221.
} 
ser produzidas, não determinando o conteúdo da norma a produzir. ${ }^{12}$

Não obstante, o entendimento doutrinário e jurisprudencial atualmente pacificado é o defendido por Clèmerson Merlin Clève que, em sua obra "A Fiscalização Abstrata de Constitucionalidade no Direito Brasileiro", ao reconhecer a contribuição de Kelsen quanto ao escalonamento hierárquico das normas jurídicas, discorda deste ao dizer que o reconhecimento da Constituição como Lei Fundamental implica o reconhecimento de sua supremacia, que

"não exige apenas a compatibilidade formal do direito infraconstitucional com os seus comandos definidores do modo de produção das normas jurídicas, mas também a observância de sua dimensão material".13

A supremacia "material" da Constituição só é reconhecida, entretanto, porquê há a "supremacia formal", ${ }^{14}$ isto é, a exigência de um processo próprio para sua elaboração e alteração, mais dificultoso do que para as demais leis do sistema. A rigidez constitucional possibilita que qualquer ato em desconformidade com a Lei Maior seja declarado inconstitucional, em vez de a norma constitucional, anterior, ser revogada por lei posterior infraconstitucional.

A rigidez constitucional, portanto, é o segundo pressuposto ${ }^{15}$ - no entendimento doutrinário majoritário - para a existência do controle de constitucionalidade.

\footnotetext{
12 KELSEN, Hans. Op. cit., p. 246-249.

${ }^{13}$ CLEVE, Clèmerson Merlin. Op. cit., p. 21.

${ }^{14}$ SILVA, José Afonso da. Op. cit., p. 47-48.

${ }^{15}$ Clèmerson Cleve fala que seria até possível pensar em controle de constitucionalidade em uma Constituição Flexível, porém somente quanto à inconstitucionalidade formal. Isso, pois enquanto a inconstitucionalidade material depende totalmente da rigidez constitucional, visto que em uma constituição flexível a lei ordinária posterior poderia revogar o conteúdo de uma lei constitucional, a inconstitucionalidade formal limita-se a determinar o procedimento, motivo pelo qual a lei ordinária
} 
Sem adentrar nas espécies intermediárias de alterabilidade ${ }^{16}$ existentes entre rigidez e flexibilidade, uma Constituição flexível demanda o mesmo procedimento que as leis infraconstitucionais demandam para sua alteração, enquanto uma Constituição rígida exige procedimento mais dificultoso e complexo para sofrer qualquer mudança. ${ }^{17}$

A fiscalização da constitucionalidade ocorre apenas quando a Constituição é rígida, ${ }^{18}$ como é o caso da Constituição Republicana Brasileira de 1988, atualmente em vigor, consoante as regras procedimentais solenes de alteração previstas em seu art. $60 .{ }^{19}$

Ronaldo Poletti bem observa que as constituições escritas são presumidamente rígidas, enquanto as constituições consuetudinárias refletem uma flexibilidade maior. ${ }^{20}$

\subsection{Objetos e parâmetro de controle}

O controle de constitucionalidade, conforme asseverado, é um dos mecanismos, provavelmente o mais importante, para aferir a compatibilidade da lei ou ato normativo em face da Constituição. Resta a nós, nesse capítulo, tecer breves comentários acerca do que é considerado "lei ou ato normativo" e "Constituição" para fins de objeto e parâmetro do controle de constitucionalidade.

Em suma, o parâmetro constitucional é a norma ou conjunto de normas

\footnotetext{
elaborada em detrimento desse procedimento poderia ser objeto do controle de constitucionalidade. CLEVE, Clèmerson Merlin. Op. cit., p. 25-26.

16 Além de flexível e rígida, as constituições também pode ser classificadas, quanto à alterabilidade/mutabilidade/estabilidade, em semirrígidas, fixas, transitoriamente flexíveis, imutáveis e superrígidas. LENZA, Pedro. Op. cit., p. 85-87.

${ }^{17}$ POLETTI, Ronaldo. Controle da Constitucionalidade das Leis. Rio de Janeiro: Forense, 1995, p. 3.

${ }^{18}$ CLEVE, Clèmerson Merlin. Op. cit., p. 25.

${ }^{19}$ LENZA, Pedro. Op. cit., p. 219.

${ }^{20}$ POLETTI, Ronaldo. Op. cit. p. 2.
} 
constitucionais tomadas como referência para a aferição de inconstitucionalidade de lei ou ato normativo do poder público. Por sua vez, o objeto do controle é a lei ou ato normativo do poder público, que pode ser federal, estadual, distrital ou ainda municipal.

Sobre o tema, Clèmerson Merlin Clève diz que "todos os dispositivos constitucionais servem de parâmetro para a aferição da constitucionalidade dos atos normativos", ${ }^{21}$ incluindo preâmbulo, princípios e preceitos. Quanto ao preâmbulo, no Brasil firmou-se o entendimento que preâmbulo não pode ser parâmetro de controle, porém os princípios, explícitos e implícitos, e valores contidos no preâmbulo podem ser parâmetro para o controle de constitucionalidade.

Luís Roberto Barroso vai ao encontro do entendimento de Clèmerson, dizendo que o controle de constitucionalidade "pode ter como parâmetro todas as categorias de normas constitucionais: de organização, definidoras de direitos e programáticas". ${ }^{22}$

O parâmetro para o controle de constitucionalidade, bem verdade, não é só a Constituição Federal, mas o que podemos chamar de bloco de constitucionalidade, que abarca o texto Constitucional em sua totalidade, considerando as regras, princípios e valores constitucionais, o ADCT, as Emendas Constitucionais, e os tratados internacionais de direitos humanos votados na forma de Emenda Constitucional, consoante previsão do $\S 3^{\circ}$ do art. $5^{\circ}$ da Magna Carta.

Por sua vez, podem ser objeto da aferição de (in)constitucionalidade as emendas constitucionais, a lei ordinária, a lei complementar, a medida provisória, a lei delegada, as resoluções, o decreto legislativo, o decreto

\footnotetext{
${ }^{21}$ CLEVE, Clèmerson Merlin. Op. cit., p. 33-34.

${ }^{22}$ BARROSO, Luís Roberto. Op. cit., p. 51.
} 
autônomo, o regimento interno de tribunal, resoluções do CNJ e do CNMP e os decretos legislativo e executivo que internalizam tratado nacional.

Todos esses tipos normativos acima citados são leis ou ato normativos primários, aqueles que retiram o seu fundamento de validade jurídica diretamente da Constituição Republicana, sem lei intermediária. Em regra, o objeto deve estar ligado de forma imediata à Carta Magna. ${ }^{23}$

Importante ressaltar o papel ambíguo da Emenda Constitucional, que pode ser tanto parâmetro quanto objeto do controle de constitucionalidade. Será objeto quando for feito o juízo de adequação entre esta e o texto constitucional originário, pré-existente, considerando-se as limitações constitucionais do art. 60 ao poder constituinte derivado reformador. De outra forma, será parâmetro vez que, ao ser promulgada, passa a ter força de norma constitucional, fazendo parte do bloco de constitucionalidade e tendo de ser observada pelas leis infraconstitucionais.

Outra observação válida é quanto as leis anteriores à constituição em vigor. A despeito da controvérsia doutrinária existente, conforme a corrente majoritária, estas não poderão ser objeto de controle de constitucionalidade. Isso, pois ao tempo em que foram promulgadas, quando da vigência da constituição anterior, estavam em conformidade com a Constituição e, portanto, eram constitucionais. Ao entrar em vigor novo texto constitucional, tais normas sofrerão o juízo recepção ou de revogação, não havendo de se falar em inconstitucionalidade.

\footnotetext{
${ }^{23}$ Normalmente, o objeto deve estar ligado diretamente à Constituição. No entanto, tem-se admitido Ação de Descumprimento de Preceito Fundamental - ADPF - tendo por objeto norma secundária. Atos normativos secundários são aqueles que retiram o seu fundamento de validade dos atos primários, isto é, diretamente das leis, e apenas indiretamente da Constituição. Em regra, portanto, não podem ser objeto de controle de constitucionalidade.
} 


\section{Fenômeno Da Inconstitucionalidade}

\subsection{Espécies de Inconstitucionalidade}

A doutrina costuma classificar em categorias as diferentes formas de inconstitucionalidade. $\mathrm{O}$ presente tópico discorrerá sobre as principais espécies de inconstitucionalidade, questão importantíssima para o tema deste trabalho, visto que os efeitos da declaração de inconstitucionalidade em muito dependem do tipo de inconstitucionalidade aferido em cada caso.

\subsubsection{Inconstitucionalidade por ação e por omissão}

A inconstitucionalidade ocorre devido à existência de lei incompatível com a constituição ou decorre da ausência de lei necessária para a eficácia da constituição. Falamos aqui em inconstitucionalidade por ação e por omissão, respectivamente, pois envolve aquela uma atuação positiva e esta uma atuação negativa do legislador.

A inconstitucionalidade deriva, então, ou da elaboração, aprovação, promulgação e validade de uma lei e ato normativo ou da ausência de uma lei, de sua omissão.

Esta última hipótese é uma novidade no direito, pois tradicionalmente aferíamos apenas a inconstitucionalidade por ação, que existe desde o reconhecimento da supremacia constitucional. ${ }^{24}$ Ocorre que as constituições semânticas ${ }^{25}$ do pós-segunda guerra mundial alertaram para a necessidade do

\footnotetext{
${ }^{24}$ MENDES, Gilmar Ferreira. Curso de Direito Constitucional. $6^{a}$ ed. rev. e atual. São Paulo: Saraiva, 2011, p. 1085.

${ }^{25} \mathrm{Na}$ classificação ontológica das Constituições de Löewenstein, constituição semântica é aquela que serve apenas para justificar a dominação dos que exercem o poder, não tendo formal ou materialmente nenhuma ferramenta que lhe dê efetividade. A constituição normativa, por sua vez, é aquela em que
} 
reconhecimento de que o 'não fazer' por parte do poder constituído também seria inconstitucional.

A omissão não se resume apenas a um "não fazer", a um simples conceito de negação. A omissão aqui significa deixar de fazer aquilo que se estava constitucionalmente obrigado.

$\mathrm{Ou}$ seja, a omissão inconstitucional decorre de uma lacuna constitucional deixada pelo constituinte para o legislador agir. Estamos falando, em suma, da existência de norma de eficácia limitada, e não de mera abertura do ordenamento jurídico. ${ }^{26}$

Normas constitucionais de eficácia limitada são aquelas de aplicação mediata/indireta, que necessitam de norma infraconstitucional regulamentadora. A não atuação do legislativo gera uma situação de inconstitucionalidade, na medida em que a norma constitucional não gerará efeitos finalísticos para os quais foi criada.

Pode existir também o caso de omissão parcial, ou seja, existir uma lei regulamentadora, porém esta não satisfaz aquilo que a norma constitucional prevê, por atender parcialmente aos seus ditames ou de forma insuficiente. ${ }^{27} \mathrm{~A}$ solução para essa hipótese de cumprimento parcial do dever de legislar será abordada no capítulo 5, quando falarmos dos efeitos da declaração de inconstitucionalidade.

\subsubsection{Inconstitucionalidade material e formal}

suas disposições regulam o processo político e, em contrapartida, o Poder observa suas disposição. Aqui, há uma real efetividade da constituição, que reflete a sociedade e é refletida nela. Por fim, a constituição nominal é aquela juridicamente válida, mas que acaba por não se manifestar no mundo dos fatos devido à realidade política vivida.

${ }^{26}$ CLEVE, Clèmerson Merlin. Op. cit., p. 42.

${ }^{27}$ MENDES, Gilmar Ferreira. Op. cit., p.1085. 
A distinção entre inconstitucionalidade material e formal não é apenas didática, mas de extrema importância prática, sobretudo quanto aos efeitos da declaração de inconstitucionalidade, os quais oportunamente analisaremos em outro capítulo. Por ora, resta-nos distinguir as duas espécies.

A inconstitucionalidade material existe, pois a lei ou ato normativo padecem de um vício substantivo, isto é, há uma inadequação do conteúdo da lei ou ato normativo em face da constituição. ${ }^{28}$ Assim, o ato normativo tem de ser compatível com o conteúdo da Lei Fundamental, considerando que todos os seus dispositivos servem de parâmetro para a aferição de constitucionalidade da norma, conforme já mencionado. ${ }^{29}$

Gilmar Ferreira Mendes lembra, porém, que a inconstitucionalidade material pode ocorrer não só do "contraste direto do ato legislativo com o parâmetro constitucional, mas também [d]a aferição do desvio de poder ou do excesso de poder legislativo", ${ }^{30}$ que ocorre quando o legislativo não respeita o princípio da proporcionalidade, isto é, não observa a adequação e necessidade do ato legislativo.

Já a inconstitucionalidade formal ocorre devido a um defeito objetivo, de procedimento, pressuposto ou competência inobservado quando da feitura da lei ou ato normativo. ${ }^{31}$ Nesse caso, o vício não reside no conteúdo, mas na forma da norma infraconstitucional, em sua formação.

Existem três tipos de inconstitucionalidade formal: a orgânica, a formal propriamente dita, e a por violação a pressupostos objetivos do ato. ${ }^{32} \mathrm{~A}$ inconstitucionalidade formal orgânica decorre da inobservância da

\footnotetext{
${ }^{28}$ MENDES, Gilmar Ferreira. Op. cit., p.1072.

${ }^{29}$ CLEVE, Clèmerson Merlin. Op. cit., p. 33-34.

${ }^{30}$ MENDES, Gilmar Ferreira. Op. cit., p. 1072.

${ }^{31}$ MENDES, Gilmar Ferreira. Op. cit., p.1070.

${ }^{32}$ LENZA, Pedro. Op. cit., p. 231.
} 
competência legislativa constitucionalmente prevista para elaboração da norma.

Já a inconstitucionalidade formal propriamente dita decorre da inobservância ao devido processo legislativo, que pode ocorrer ou na fase de iniciativa ou das demais fases de elaboração da norma. ${ }^{33}$

O vício de iniciativa, primeira subespécie da inconstitucionalidade formal propriamente dita, é um vício formal subjetivo, que se refere àquele que teve a iniciativa do projeto de lei. Ou seja, aqui, o sujeito ou ente que detinha a iniciativa para a propositura do projeto de lei não foi aquele que efetivamente o fez. ${ }^{34}$

Há, como segunda e última subespécie da inconstitucionalidade formal propriamente dita, o vício formal objetivo, que é aquele que ocorre nas demais fases do processo legislativo, consistente em um defeito procedimental na elaboração da norma, isto é, um vício na sua exteriorização. ${ }^{35}$

Por fim, há a inconstitucionalidade formal por violação a pressupostos objetivos do ato. Nesse caso, o vício ocorreu antes do processo legislativo, com a inobservância de pressupostos constitucionalmente previstos para que aquele ato pudesse ser elaborado.

\subsubsection{Inconstitucionalidade total e parcial}

A inconstitucionalidade pode ser total ou parcial e o critério para classificar é o conjunto ou as partes atingidas pela constitucionalidade. A inconstitucionalidade será total quando contaminar todo o ato e será parcial se

\footnotetext{
${ }^{33}$ BARROSO, Luís Roberto. Op. cit., p. 49-50.

${ }^{34}$ LENZA, Pedro. Op. cit., p. 232-233.

${ }^{35}$ LENZA, Pedro. Op. cit., p. 232-233.
} 
o vício incidir em apenas parcela dele. ${ }^{36}$

A inconstitucionalidade formal, em regra, é inconstitucionalidade total. ${ }^{37}$ Isto, pois se a norma foi elaborada em contrariedade ao procedimento constitucionalmente previsto, com algum vício de competência, iniciativa ou outro vício de forma, então toda ela padecerá de inconstitucionalidade.

Claramente, há exceções, como, por exemplo, quando uma lei ordinária dispõe sobre mais de uma questão, sendo que uma delas deveria ser regulamentada por lei complementar. Nesse exemplo, apesar do vício ser formal, a declaração de inconstitucionalidade recairá apenas sobre a parte que deveria ter sido disposta em lei complementar, isto é, a lei promulgada será parcialmente inconstitucional, podendo ser mantida em vigor a parte constitucional. ${ }^{38}$

Já a inconstitucionalidade material pode ser total ou parcial. Se atingir um dispositivo, um artigo, apenas um capítulo, e não todo seu conteúdo, será parcialmente inconstitucional. ${ }^{39}$ Não há, entretanto, de se admitir a constitucionalidade de parte do dispositivo se isto alterar seu sentido.

Estamos falando da possibilidade de a inconstitucionalidade parcial gerar uma inconstitucionalidade total, e isso acontecerá sempre que não for possível separar a parte viciada da parte não viciada. Isso ocorrerá quando a parte constitucional não possuir significado autônomo, sendo dependente da parte viciada. Também ocorrerá quando houver uma relação de interdependência.

O Supremo tem, nos últimos tempos, utilizado algumas técnicas importante quando da declaração de inconstitucionalidade parcial, quais sejam

\footnotetext{
${ }^{36}$ CLEVE, Clèmerson Merlin. Op. cit., p. 37-38.

${ }^{37}$ BARROSO, Luís Roberto. Op. cit., p. 61.

${ }^{38}$ CLEVE, Clèmerson Merlin. Op. cit., p. 39.

${ }^{39}$ CLEVE, Clèmerson Merlin. Op. cit., p. 39.
} 
o agravamento do estado de inconstitucionalidade, a declaração parcial sem redução de texto e a interpretação conforme a constituição, técnicas estas que serão tempestivamente explicadas no capítulo 5 do presente trabalho.

\subsubsection{Inconstitucionalidade originária e superveniente}

Por fim, podemos diferenciar a inconstitucionalidade originária da superveniente. O critério de classificação é o momento em que o texto legal ou normativo da administração é verificado face à Constituição da República. Há uma inconstitucionalidade originária quando a lei/ato normativo é incompatível com a constituição no momento em que ingressa no mundo jurídico. $^{40}$

Por vezes, reconhecemos também uma inconstitucionalidade superveniente, que só ocorre no Brasil quando há a mutação constitucional. ${ }^{41}$ Enquanto a emenda à constituição e a revisão constitucional são espécies de alteração formal da constituição, a mutação constitucional é a alteração informal da Lei Maior, isto pois não ocorre mudança no texto da constituição, mas mudança de interpretação de um dispositivo constitucional.

A mudança de interpretação modifica o parâmetro de controle, o que pode gerar a inconstitucionalidade superveniente de uma norma antes constitucional.

Importante observar que, a despeito da controvérsia doutrinária, o entendimento jurisprudencial que prevalece ${ }^{42}$ é que uma norma feita sob a

\footnotetext{
${ }^{40}$ BARROSO, Luís Roberto. Op. cit., p. 62-63.

${ }^{41}$ MENDES, Gilmar Ferreira. Op. cit., p. 1074.

${ }^{42}$ Nesse sentido, destaca-se a ementa da ADI nº 02: "CONSTITUIÇÃO. LEI ANTERIOR QUE A CONTRARIE. REVOGAÇÃO. INCONSTITUCIONALIDADE SUPERVENIENTE.

IMPOSSIBILIDADE. 1. A lei ou é constitucional ou não é lei. Lei inconstitucional é uma contradição em si. A lei é constitucional quando fiel à Constituição; inconstitucional na medida em que a desrespeita, dispondo sobre o que lhe era vedado. $\mathrm{O}$ vício da inconstitucionalidade é congênito à lei e
} 
égide de uma constituição anterior que seja incompatível com a nova constituição não padece do vício de inconstitucionalidade superveniente. Nesse caso, ela não é recepcionada, ou, em outros termos, é revogada. A norma anterior à Constituição em vigor só será revogada se for incompatível materialmente com esta. Caso a divergência seja na forma, a norma haverá de ser recepcionada.

Da mesma forma, quando uma lei ou ato normativo é constitucional, mas o legislativo aprova emenda constitucional alterando o parâmetro de constitucionalidade desta lei, tornando-a colidente com a nova redação, não será caso de inconstitucionalidade superveniente, mas de não recepção/revogação da norma anterior ao parâmetro, que, no caso, será a EC.

\subsection{Os planos de existência, validade e eficácia da norma inconstitucional}

As normas e atos normativos jurídicos são analisados em três planos distintos: existência, validade e eficácia. A conceituação e distinção entre essas categorias são de suma importância ao estudo dos efeitos da declaração de inconstitucionalidade, conforme veremos adiante.

Podemos dizer que um ato jurídico, ou norma jurídica mais especificamente, existe quando estão presentes os elementos constitutivos previstos pela lei como causa para sua incidência. Os mais comuns são agente,

há de ser apurado em face da Constituição vigente ao tempo de sua elaboração. Lei anterior não pode ser inconstitucional em relação à Constituição superveniente; nem o legislador poderia infringir Constituição futura. A Constituição sobrevinda não torna inconstitucionais leis anteriores com ela conflitantes: revoga-as. Pelo fato de ser superior, a Constituição não deixa de produzir efeitos revogatórios. Seria ilógico que a lei fundamental, por ser suprema, não revogasse, ao ser promulgada, leis ordinárias. A lei maior valeria menos que a lei ordinária. 2. Reafirmação da antiga jurisprudência do STF, mais que cinquentenária. 3. Ação direta de que se não conhece por impossibilidade jurídica do pedido". (STF - ADI nº 02/DF, rel. Min. Paulo Brossard, Brasília, 06 fev. 1992). 
objeto e forma, mas a lei pode prever outros elementos específicos para determinados atos. ${ }^{43}$

Nesse caso, caso um desses elementos inexista ou seja defeituoso, o ato será inexistente e, portanto, repelido do Direito.

Quanto ao plano da validade, será considerada válida a norma na qual estejam presentes os requisitos que a lei previu para que essa norma seja perfeita. Assim, agente, objeto e forma fazem um ato existir, mas para que este seja perfeito e, consequentemente, válido, o agente tem de ser competente, o objeto lícito e possível e a forma adequada, seja verbal ou escrita, consoante previsão legal. $^{44}$

Caso algum desses requisitos esteja ausente, o ato será inválido, cuja sanção será a nulidade ou anulabilidade, a depender da gravidade do vício.

Aqui é onde entra a norma inconstitucional, que ingressou e incidiu no mundo jurídico sendo, portanto, existente, mas que não pode ser considerada válida, pois em desconformidade com o ordenamento jurídico superior, qual seja, a Lei Fundamental.

A sanção da norma inconstitucional que, portanto, padece do vício de invalidade, haverá de ser sua anulabilidade ou nulidade, determinada conforme o sistema de controle adotado em cada Estado.

No controle de constitucionalidade norte-americano, aplica-se a sanção mais grave de nulidade. $\mathrm{O}$ ato inconstitucional é considerado nulo de pleno direito, visto ter nascido morto. Assim, a decisão sobre a inconstitucionalidade é meramente declaratória de um vício preexistente, e, portanto, seus efeitos deverão retroagir à data de promulgação do ato (efeitos ex tunc). ${ }^{45}$

Já no controle de constitucionalidade austríaco, o entendimento que

\footnotetext{
${ }^{43}$ BARROSO, Luís Roberto. Op. cit., p. 34-35.

${ }^{44}$ BARROSO, Luís Roberto. Op. cit., p. 35.

${ }^{45}$ LENZA, Pedro. Op. cit., p. 220.
} 
prevaleceu foi o de que a norma inconstitucional é anulável, sendo a decisão que reconhece a inconstitucionalidade constitutiva e, portanto, efeitos em regra ex nunc, i.e., prospectivos. ${ }^{46}$ Falaremos sobre o controle de constitucionalidade no direito externo no próximo capítulo.

Por terceiro e último plano temos a eficácia dos atos jurídicos que se dá devido à sua aptidão para produzir efeitos, atingindo a finalidade para a qual foram gerados. A eficácia, conforme sintetiza Barroso, "diz respeito, assim, à aplicabilidade, exigibilidade ou executoriedade da norma". ${ }^{47}$

Conforme estudado acima, a inconstitucionalidade é um vício no plano da validade da norma. A invalidade da norma se manifestará no plano seguinte, qual seja o da eficácia, pois a norma inconstitucional não pode ser aplicada, tampouco exigida.

A ineficácia da norma inconstitucional no sistema brasileiro de controle incidirá sobre todos, erga omnes, quando da declaração de inconstitucionalidade em ação direta do controle. ${ }^{48}$ Esse tema será aprofundado nos capítulos 4 e 5 da presente monografia.

Vale, por fim, observar que, não obstante a inaplicabilidade da norma inconstitucional, esta não sofrerá um ato formal que a elimine do mundo jurídico. Assim sendo, embora inválida e ineficaz, continuará a existir. ${ }^{49}$

\footnotetext{
${ }^{46}$ LENZA, Pedro. Op. cit., p. 221.

${ }^{47}$ BARROSO, Luís Roberto. Op. cit., p. 36.

${ }^{48}$ ZAVASCKI, Teori Albino. Eficácia das Sentenças na Jurisdição Constitucional. $3^{\mathrm{a}}$ ed. rev., atual. e ampl. São Paulo: Editora Revista dos Tribunais, 2014, p. 64

${ }^{49}$ BARROSO, Luís Roberto. Op. cit., p. 37.
} 


\section{Principais Modelos de Controle e suas respectivas Decisões de Inconstitucionalidade}

O presente capítulo visa fazer uma introdução histórica do surgimento e evolução do controle de constitucionalidade em outros ordenamentos jurídicos, com enfoque nas decisões de inconstitucionalidade e seus efeitos subjetivos, objetivos e temporais.

Conforme veremos no capítulo 4, os diferentes sistemas de controle de constitucionalidade influenciaram e serviram de base ao controle de constitucionalidade brasileiro, cada um em um peso e uma medida, sobretudo no que tange às declarações de inconstitucionalidade proferidas pelo poder judiciário brasileiro.

\subsection{Modelo norte-americano - O Controle Judicial Difuso}

O reconhecimento da supremacia da Constituição, já estudada anteriormente, data desde antigos sistemas jurídicos, tais quais o ateniense e o medieval. Não obstante, o amadurecimento desse conceito e de suas consequências práticas, como a necessidade de haver um controle de constitucionalidade, teve início nos Estados Unidos quando do julgamento do caso Marbury v. Madison pela Suprema Corte americana em 1803.

Os fatos que levaram ao litígio em questão derivam, em suma, de uma disputa política entre o ex-presidente John Adams e o então atual presidente Thomas Jefferson. Sem adentrar nas causas e questões políticas, o fato é que o julgamento e o voto do presidente da suprema corte, Marshall, inaugurou o controle de constitucionalidade moderno, assentando "o princípio da 
Supremacia da Constituição, da subordinação a ela de todos os poderes Estatais e da competência do judiciário como seu intérprete final, podendo invalidar os atos que lhe convenham", como bem resume Barroso. ${ }^{50}$

O princípio da Supremacia da Constituição e do judiciário como guardião da Constituição, apesar de terem ganhado visibilidade com Marshall vs. Madison, já tinham sido tratados no artigo 78 do Federalista por Alexander Hamilton. Disse ele que a fiscalização das leis pelo judiciário não significava a preponderância de um poder em relação ao outro, mas a supremacia do poder do povo, manifestada na Constituição, em detrimento da legislação com ela incompatível. ${ }^{51}$

O sistema americano adotou o controle jurisdicional difuso, exercido, portanto, por todo e qualquer órgão do poder judiciário, a qualquer tempo, em qualquer grau de jurisdição ou instância. ${ }^{52}$

O sistema difuso baseia-se na lógica interpretação das leis pelo juiz diante do caso concreto. Em caso de leis contrastantes, deve o juiz aplicar a prevalecente, utilizando-se de um critério: lei posterior derroga lei anterior; lei específica derroga lei geral; e, em se tratando de conflito entre lei infraconstitucional e constitucional, lei superior derroga lei inferior. ${ }^{53}$

Esta espécie de controle tem, a princípio, o condão de trazer incerteza ao direito e insegurança jurídica às relações por ele disciplinadas. ${ }^{54}$ Digo "a princípio", pois esses problemas foram atenuados nos países de common law, como os Estados Unidos, através do princípio do stare decisis, segundo o qual

\footnotetext{
${ }^{50}$ BARROSO, Luís Roberto. Op. cit., p. 32.

${ }^{51}$ HAMILTON, Alexander. The Federalist no. 78. Independent Journal. Sábado, 14 de junho de 1788, em: http://www.constitucion.org/fed/federa78.htm

${ }^{52}$ CLEVE, Clèmerson Merlin. Op. cit., p. 50.

${ }^{53}$ CAPPELLETTI, Mauro. O Controle Judicial de Constitucionalidade das Leis no Direito

Comparado. Porto Alegre: S.A. Fabris, 1985, p. 75

${ }^{54}$ POLETTI, Ronaldo. Op. cit., p. 60-61.
} 
a decisão pela mais alta corte em qualquer jurisdição, em especial a Suprema Corte, vincula todas os órgãos judiciários daquela jurisdição. ${ }^{55}$

No stare decisis, a decisão de inconstitucionalidade de uma lei acaba por ter eficácia erga omnes. Nesse caso, apesar de continuar existindo, torna-se uma lei morta, não mais aplicável. No stare decisis, a lógica do controle de constitucionalidade como mera interpretação diante do caso concreto não faz mais sentido, pois não estamos falando mais de mera "não aplicação" de uma lei, mas, na prática, uma eliminação da lei inconstitucional, com efeitos para todos. ${ }^{56}$

O controle difuso ocorre pela via incidental, ${ }^{57}$ através de uma exceção de inconstitucionalidade oposta como preliminar na contestação do réu, cuja eficácia limitar-se-á ao caso concreto, ou seja, inter partes. Apenas a decisão de inconstitucionalidade proferida pela Suprema Corte, conforme mencionado no parágrafo acima, produz efeitos erga omnes e vinculantes para todos os demais órgãos judiciais. ${ }^{58}$

No caso Marbury v. Madison (e no sistema norte-americano), adotou-se a Teoria da Nulidade quando da declaração de inconstitucionalidade da norma, ou seja, a lei inconstitucional é considerada absolutamente nula, pois contrária à norma superior e, portanto, ineficaz. ${ }^{59}$

A decisão de inconstitucionalidade será meramente declaratória, reconhecendo uma situação preexistente, qual seja a nulidade da norma, sua invalidade e consequente ineficácia da mesma. ${ }^{60} \mathrm{~A}$ decisão produzirá efeitos ex tunc, i.e., retroativos, pois a lei nasceu morta devido à sua inadequação com o

\footnotetext{
${ }^{55}$ CAPPELLETTI, Mauro. Op. cit., p. 80-81.

${ }^{56}$ CAPPELLETTI, Mauro. Op. cit., p. 82.

${ }^{57}$ CAPPELLETTI, Mauro. Op. cit., p. 102.

${ }^{58}$ POLETTI, Ronaldo. Op. cit., p. 61.

${ }^{59}$ CAPPELLETTI, Mauro. Op. cit., p. 115-116.

${ }^{60}$ LENZA, Pedro. Op. cit., p. 220-221.
} 
paradigma de controle - o bloco de constitucionalidade. ${ }^{61}$

Sistema análogo de controle foi adotado, por exemplo, no Canadá, no Japão, na Noruega na Dinamarca e, mais recentemente, na Suécia. ${ }^{62}$

\subsection{Modelo austríaco - O Sistema de Jurisdição Concentrada}

Enquanto na América do Norte Marshall ofereceu enorme contribuição ao controle de constitucionalidade, na Europa esse papel foi de Hans Kelsen, através da Constituição da Áustria de 1920.

$\mathrm{Na}$ Áustria, por influência francesa, o Parlamento adquiriu notável soberania, sendo impensável falar em controle do Judiciário de ato do Legislativo, como ocorre no modelo de judicial review norte-americano. Para Kelsen, o controle de constitucionalidade não é atividade judicial, mas atividade constitucional, comparável à função legislativa negativa, que deveria ser realizada por uma Corte Constitucional. ${ }^{63}$

A Corte Constitucional é um órgão especial, de natureza jurídicopolítica. Aqui, o controle não é nem atividade judicial, exercida pelo Judiciário, conforme o modelo norte-americano, nem atividade política, exercida pelo Legislativo, a exemplo do que ocorre na França. ${ }^{64}$

O sistema concentrado de controle adotado na Áustria pauta-se não na lógica de interpretação da lei, mas na doutrina da supremacia da lei e na clara separação de poderes. A constituição austríaca proíbe expressamente a apreciação da validade das leis pelos tribunais. ${ }^{65}$

Apenas a Corte Constitucional possui a competência de julgar a

\footnotetext{
${ }^{61}$ CAPPELLETTI, Mauro. Op. cit., p. 117.

${ }^{62}$ CAPPELLETTI, Mauro. Op. cit., p. 102.

${ }^{63}$ CLEVE, Clèmerson Merlin. Op. cit., p. 54.

${ }^{64}$ POLETTI, Ronaldo. Op. cit., p. 63.

${ }^{65}$ CAPPELLETTI, Mauro. Op. cit., p. 84-85.
} 
adequação das normas em face da Carta Magna. Ao contrário do sistema americano, cujo controle é exercido de forma incidental, no sistema austríaco é exercido em via principal, em via de ação, com a instauração de adequado e autônomo processo perante a Corte Constitucional. ${ }^{66}$ Constatada a inconstitucionalidade, a Corte proferirá sentença anulando a lei viciada, que deixará de existir no prazo máximo de seis meses. ${ }^{67}$

Segundo a Teoria da Anulabilidade de Kelsen, materializada no modelo austríaco, a lei inconstitucional é válida e produz efeitos até que a Corte Constitucional pronuncie sobre a sua inconstitucionalidade, momento em a lei será anulada, cassada. Assim, a decisão terá natureza constitutiva negativa, retirando do mundo jurídico a lei, que passará a não mais produzir efeitos.

A decisão da Corte Constitucional terá, via de regra, efeitos ex nunc, não retroativos, valendo apenas a partir da data da publicação da decisão. Pode ainda, por uma discricionariedade da Corte, ter efeitos prospectivos, também chamados pró-futuros, caso em que a anulação da lei operará a partir de uma data posterior à publicação, não superior a um ano. ${ }^{68}$

A decisão de inconstitucionalidade no controle austríaco abstrato terá eficácia erga omnes, ou seja, a lei inconstitucional tornar-se-á ineficaz para todos. Essa decisão também terá o que entendemos por efeitos repristinatórios, fazendo entrar novamente em vigor a lei que pré-existiu à lei inconstitucional, salvo se a Corte dispuser em contrário. ${ }^{69}$

Importante observar que, se antes só havia o controle abstrato exercido pela Corte Constitucional, com a reforma constitucional de 1929 o controle concreto de constitucionalidade é introduzido no modelo austríaco, cuja

\footnotetext{
${ }^{66}$ CAPPELLETTI, Mauro. Op. cit., p. 105.

${ }^{67}$ POLETTI, Ronaldo. Op. cit., p. 63.

${ }^{68}$ CAPPELLETTI, Mauro. Op. cit., p. 116-117.

${ }^{69}$ CAPPELLETTI, Mauro. Op. cit., p. 118.
} 
competência decisória também é da Corte Constitucional, mas podendo ser suscitado pelos dois órgãos jurisdicionais de segunda instância. A decisão de inconstitucionalidade, nesse caso, produzirá efeitos ex tunc, i.e., retroagirão à data do nascimento da lei e sua eficácia será meramente inter partes. ${ }^{70}$

As Cortes Constitucionais também foram adotadas na Tchecoslováquia, em 1920, no Chile, em 1925, na Espanha Republicana, em 1931, na Itália, em 1947, na Alemanha Federal, em 1949, no Chipre, em 1960, na Turquia, em 1961 e na Guatemala, em 1965. ${ }^{71}$

Na Itália e na Alemanha, assim como ocorre na Áustria, os juízes comuns não são competentes para exercer o controle de constitucionalidade. Entretanto, em ambos os países, qualquer juízo, mesmo de primeiras instâncias, possui a legitimidade - e o poder-dever - de submeter uma lei que acredite ser inconstitucional à análise da Corte Constitucional. O julgamento do caso concreto, nesse caso, ficará suspenso até que a Corte decida sobre a questão prejudicial de constitucionalidade. ${ }^{72}$

Ainda sobre esses dois países, Itália e Alemanha, as decisões das respectivas Cortes Constitucionais têm eficácia erga omnes, tal qual ocorre na Áustria. Entretanto, podemos notar mais uma diferença entre este e aqueles países: enquanto na Áustria os efeitos são ex nunc, na Alemanha e Itália os efeitos operarão ex tunc pois, nesses dois países, a inconstitucionalidade é considerada causa de nulidade absoluta. ${ }^{73}$

\subsection{Outros modelos}

\subsubsection{Modelo Francês - O Controle Político}

\footnotetext{
${ }^{70}$ CLEVE, Clèmerson Merlin. Op. cit., p. 55.

${ }^{71}$ POLETTI, Ronaldo. Op. cit., p. 63.

${ }^{72}$ CAPPELLETTI, Mauro. Op. cit., p. 109.
} 
O modelo francês destaca-se pela enfática separação de poderes, em que um poder não interfere no outro. De antemão, já podemos dizer que seria impossível, então, o judiciário fazer o controle de um ato emanado do poder legislativo. Resta ao judiciário tão somente aplicar a lei, e não legislar. ${ }^{74}$

Ademais, o legislador representa a coletividade nacional e a sua vontade e, portanto, deve ser o próprio poder legislativo a exercer o controle de constitucionalidade das leis. Assim, o modelo francês possui o controle político de constitucionalidade, visto ser exercido por um órgão político, o legislativo. $^{75}$

Além desses dois aspectos ideológicos, há um motivo histórico para o controle ser exercido pelo legislativo, que é a desconfiança em relação aos tribunais do antigo regime, derrubado pela Revolução Francesa. No antigo regime, a jurisdição era exercida como um direito patrimonial pelos juízes, de forma arbitrária e abusiva. ${ }^{76}$

Acrescenta Cappelletti uma razão prática para esse sistema, que é a de assegurar, sobretudo, uma tutela contra as ilegalidades e abusos do executivo e do judiciário, antes de assegurar uma tutela contra excessos do poder legislativo. ${ }^{77}$

Assim, na França, o controle de constitucionalidade sempre foi feito pelo próprio Parlamento e de forma preventiva, isto é, antes da norma entrar em vigor. A vantagem, ao contrário do que ocorre no modelo norte-americano, é a assegurar à lei o caráter de certeza, segurança jurídica, visto não ser

\footnotetext{
${ }^{73}$ CAPPELLETTI, Mauro. Op. cit., p. 119.

${ }^{74}$ CLEVE, Clèmerson Merlin. Op. cit., p. 47.

${ }_{76}^{75}$ POLETTI, Ronaldo. Op. cit., p. 56.

${ }^{76}$ CLEVE, Clèmerson Merlin. Op. cit., p. 48.

${ }^{77}$ CAPPELLETTI, Mauro. Op. cit., p. 98.
} 
possível controle posterior. ${ }^{78}$

O problema é que há pouca objetividade nesse tipo de controle, exercido muitas vezes por critérios meramente políticos. Não há aqui uma separação de poderes menos rígida como no sistema norte-americano onde vigora a mecânica de freios e contra-pesos, com interferências recíprocas entre os poderes do Estado. ${ }^{79}$

Além do Parlamento, há ainda o Conselho Constitucional - previsto na Carta de 1958 -, órgão político criado para exercer o controle preventivo de constitucionalidade, que ocorre depois da aprovação, porém antes da promulgação da lei ou ato normativo. ${ }^{80}$

Ocorre que, em 2008, uma reforma constitucional modificou a Constituição de 1958, ainda em vigor, passando a permitir o controle repressivo da constitucionalidade das leis, também de competência do Conselho Constitucional, que coexiste com o controle preventivo. ${ }^{81}$

Essa inovação, que alterou significativamente o modelo francês de controle, consiste na possibilidade de qualquer pessoa, parte em processo judicial ou administrativo, suscitar a inconstitucionalidade de uma lei relevante ao caso, contanto que a lei já não tenha sido declarada constitucional na fiscalização preventiva.

O sistema de controle originário, preventivo, foi incorporado na Holanda, na Finlândia e na Alemanha, apesar de que nesta última foi criado um Tribunal de Justiça Constitucional para exercer a jurisdição constitucional.

\subsubsection{Modelo Português - O Sistema Misto de Controle}

\footnotetext{
${ }^{78}$ CLEVE, Clèmerson Merlin. Op. cit., p. 50.

${ }^{79}$ CAPPELLETTI, Mauro. Op. cit., p. 98.

${ }^{80}$ POLETTI, Ronaldo. Op. cit., p. 57.

${ }^{81}$ CUNHA Jr., Dirley da. O Controle de Constitucionalidade na França e as alterações advindas da Reforma Constitucional de 23 de julho de 2008. p. 6-10.
} 
A Lei Fundamental portuguesa de 1976 adotou o sistema misto de controle, que ocorre tanto pela jurisdição difusa quanto pela concentrada, "através da ação e da exceção, na via preventiva e a posteriori, em abstrato e concretamente". ${ }^{82}$ Há a previsão, inclusive, da inconstitucionalidade por omissão.

Ocorre tal qual no sistema brasileiro pela via difusa, pois os tribunais não devem aplicar ao caso concreto as normas que firam a Constituição. Existe recurso dessa decisão para o Tribunal Constitucional, semelhante ao nosso recurso extraordinário.

Também ocorre o controle concentrado, por via de ação direta, com competência exclusiva do Tribunal Constitucional, cuja decisão de inconstitucionalidade terá efeitos gerais e obrigatórios.

\subsubsection{Modelo inglês - A Ausência de Controle}

Na Inglaterra, o movimento constitucionalista das revoluções burguesas não exerceu grande influência. $\mathrm{O}$ direito inglês continuou pautado nos costumes, apesar de ter adotado algumas leis escritas.

Por ser costumeira, não se rege pela mesma lógica das constituições escritas, não havendo como distinguir formalmente as leis constitucionais das demais leis. Aqui falamos em Constituição unicamente sob o aspecto material, que inclui os mais importantes costumes e práticas do país. ${ }^{83}$

Além disso, desde a Revolução Gloriosa prevalece o princípio da supremacia do Parlamento e não da supremacia da Constituição. À vontade do Parlamento não são oponíveis barreiras, sendo ilimitada. Por esses dois

\footnotetext{
${ }^{82}$ POLETTI, Ronaldo. Op. cit., p. 66-68.

${ }^{83}$ CLEVE, Clèmerson Merlin. Op. cit., p. 46.
} 
motivos, inexistência de Constituição escrita e poder ilimitado do parlamento, não há se de falar em controle de constitucionalidade das leis e atos normativos. ${ }^{84}$

\footnotetext{
${ }^{84}$ CLEVE, Clèmerson Merlin. Op. cit., p. 47.
} 


\section{Evolução do Controle de Constitucionalidade e a Fiscalização Abstrata da Constitucionalidade no Brasil}

Após estudarmos os diferentes modelos de controle existentes no direito externo, ficará mais fácil entendermos o caminho percorrido pelo direito brasileiro, que desaguou no atual sistema de controle de constitucionalidade. Isto, pois o direito constitucional pátrio, sobretudo quanto ao mecanismo de fiscalização das leis, sofreu múltiplas influências externas, primeiro do modelo Inglês e Francês, depois do modelo difuso norte-americano e, enfim, do modelo de controle concentrado austríaco.

\subsection{Antecedentes ao modelo em vigor}

\subsubsection{Constituição de 1824}

A Constituição de 1824, primeira Constituição brasileira, não previu qualquer sistema de controle de constitucionalidade tal como hoje existe. A atribuição para a fiscalização das leis não foi outorgada ao Poder Judiciário, mas ao Poder Legislativo, um reflexo da influência do direito público francês e inglês na Constituição Imperial. ${ }^{85}$

Conforme vimos no capítulo anterior, na Inglaterra vigorava o princípio da Supremacia do Parlamento que, somado ao fato de inexistir uma constituição escrita, inviabilizara qualquer forma de controle. Já o constitucionalismo francês é marcado, sobretudo, pela absoluta separação de poderes, sendo impensável falar em controle de atos legislativos pelo judiciário. ${ }^{86}$

\footnotetext{
${ }^{85}$ CLEVE, Clèmerson Merlin. Op. cit., p. 63-64.

${ }^{86}$ POLETTI, Ronaldo. Op. cit., p. 71-72.
} 
Além da influência do direito europeu então em vigor, a existência de um quarto poder, o Poder Moderador impediu a existência do controle jurisdicional de constitucionalidade. $\mathrm{O}$ poder moderador era delegado privativamente ao Imperador e estava acima dos demais poderes, tendo por atribuição assegurar a "independência, equilíbrio e harmonia dos demais poderes" (art. 98).

Ou seja, cabia ao Poder Moderador solucionar quaisquer conflitos entre os poderes e zelar para que cada um se mantivesse com suas atribuições, sem qualquer intervenção um no outro. Atribuir ao judiciário o controle de constitucionalidade dos atos legislativos seria controverso e nada razoável, pois significaria admitir a interferência de um poder no outro. ${ }^{87}$

Assim, a Constituição de 1824 concedeu ao Poder Legislativo, delegado à assembleia geral (art. 13), a competência para fazer leis, interpretá-las, suspendê-las e revogá-las e para velar pela guarda da Constituição (art. 15). Ao poder judiciário cabia apenas aplicar as leis, sem questioná-las. ${ }^{88}$

\subsubsection{Constituição de 1891}

Sob forte influência da doutrina norte-americana, o Brasil instaurou um novo sistema constitucional. Adotou a República, a forma federativa de estado, o presidencialismo, a judicial review e criou a Suprema Corte. ${ }^{89}$

O Decreto 510, de 1890, criou a Constituição Provisória que, assim como a Constituição Imperial, arrolou a guarda da Constituição e das leis como competência do poder legislativo, agora na figura do Congresso Nacional. ${ }^{90}$

A Carta Provisória trouxe, porém, algumas novidades. A primeira foi o

\footnotetext{
${ }^{87}$ POLETTI, Ronaldo. Op. cit., p. 73

${ }^{88}$ MENDES, Gilmar Ferreira. Op. cit., p. 1093.

${ }^{89}$ CLEVE, Clèmerson Merlin. Op. cit., p. 65.
} 
estabelecimento de um processo legislativo de criação das leis que, ao final, dependia da sanção ou veto do poder executivo na figura do Presidente da República. O veto pode se dar ou por motivo político ou jurídico, e essa última possibilidade ocorre justamente quando o executivo entende pela inconstitucionalidade do projeto de lei. Aqui estamos vendo nascer o controle preventivo de constitucionalidade pelo poder executivo. ${ }^{91}$

Outra novidade foi a outorga ao Supremo Tribunal Federal, órgão máximo da esfera judicial, da competência para julgar, em última instância, recurso em que se questione a validade das leis ou atos estaduais em face da Constituição (art. 58). Estava surgindo aqui o recurso extraordinário. ${ }^{92}$

O Decreto 848 do mesmo ano, que organizou a Justiça Federal, reafirmou o disposto na Constituição Provisória sobre a competência do STF para julgar em última instância, em recurso, sentença que verse sobre a validade de lei em face da Constituição (art. 9). Estabeleceu, ainda, que "na guarda e aplicação da Constituição e das leis nacionais a magistratura só intervirá em espécie e por provocação de parte" (art. 3). ${ }^{93}$

A Constituição de 1891 absorveu as novidades dos dois decretos, mantendo, portanto, a competência do Legislativo para zelar pela guarda da Constituição, porém não privativa tal qual na Constituição de 1824, mas concorrente, assegurando a outros órgãos, tais como o Supremo, a mesma atribuição (art. 59). ${ }^{94}$

A Carta Magna foi silenciosa quanto ao controle difuso propriamente dito, falando apenas da competência dos órgãos judiciais federais para julgar causas cujo fundamento de ação ou defesa seja dispositivo constitucional.

\footnotetext{
${ }^{90}$ POLETTI, Ronaldo. Op. cit., p. 75.

${ }^{91}$ POLETTI, Ronaldo. Op. cit., p. 75.

${ }^{92}$ CLEVE, Clèmerson Merlin. Op. cit., p. 65.

${ }^{93}$ POLETTI, Ronaldo. Op. cit., p. 76.
} 
Posteriormente, a Lei ${ }^{\circ} 221$, de 1894, que completou a organização da justiça federal, adotou o controle difuso, ${ }^{95}$ expressamente em seu art. 13 , in verbis:

"Os juízes e tribunais apreciarão a validade das leis e regulamentos e deixarão de aplicar aos casos ocorrentes as leis manifestamente inconstitucionais e os regulamentos manifestamente incompatíveis com as leis ou com a Constituição".

Surgia, assim, o controle jurisdicional de constitucionalidade pela via difusa, i.e., de competência de todos os órgãos judiciais, por meio de uma exceção de inconstitucionalidade, como um incidente processual quando da apreciação de um caso concreto. Nas palavras de Pedro Lenza,

"Trata-se do denominado controle difuso de constitucionalidade, repressivo, posterior, ou aberto, pela via de exceção ou defesa, pelo qual a declaração de inconstitucionalidade se implementa de modo incidental (incidenter tantum), prejudicialmente ao mérito". 96

\subsubsection{Constituição de 1934}

A Constituição de 1934 manteve os avanços conquistados na Carta anterior, ao dispor, em seu art. 76, da competência do STF para julgar, em sede de recurso extraordinário, as causas em que se questione a validade de lei estadual ou federal em face da Constituição. ${ }^{97}$

A nova Carta trouxe ainda algumas inovações. No art. 179 previu que "só por maioria absoluta de votos da totalidade dos seus juízes, poderão os tribunais declarar a inconstitucionalidade de lei ou ato do poder público". Essa novidade é o que conhecemos hoje por reserva de plenário. ${ }^{98}$

Também inovou ao prever a competência do Senado Federal para

\footnotetext{
${ }^{94}$ POLETTI, Ronaldo. Op. cit., p. 77-78.

${ }^{95}$ POLETTI, Ronaldo. Op. cit., p. 79.

${ }_{97}^{96}$ LENZA, Pedro. Op. cit., p. 227.

${ }^{97}$ POLETTI, Ronaldo. Op. cit., p. 79.
} 
suspender a execução de lei ou ato declarados inconstitucionais pelo Poder Judiciário (art. 91). Importante observar que o dispositivo não especificou quais órgãos do poder judiciário poderiam possibilitar a suspensão da execução. Também não ficou claro se essa era uma atividade vinculada ou discricionária do Poder Legislativo. ${ }^{99}$

A suspensão da norma pelo Senado Federal dá à decisão de inconstitucionalidade que, a priori, reveste-se de efeitos inter partes - apenas aplicáveis aos litigantes do caso concreto - efeitos erga omnes, passando a valer para todos e contra todos, inclusive vinculando os demais órgãos do poder judiciário, que ficariam obrigados a não aplicar a lei declarada inconstitucional pelo Judiciário e, posteriormente, suspensa em sua execução pelo Senado. ${ }^{100}$

Além das novidades no âmbito do controle difuso, houve, pela primeira vez, a previsão de uma ação direta ao Supremo Tribunal Federal, de legitimidade exclusiva do Procurador-Geral da República, no caso de Constituição Estadual que viole princípios sensíveis da Constituição Federal. Era a Representação Interventiva. ${ }^{101}$

\subsubsection{Constituição de 1937}

A Carta de 1937, também chamada de Polaca, pois inspirada na Carta Ditatorial Polonesa de 1935, refletia o momento político ditatorial vivido à época no Brasil. Não passou de uma constituição semântica, cuja única função era formalizar o poder em benefício único dos detentores deste. ${ }^{102}$

\footnotetext{
${ }^{98}$ LENZA, Pedro. Op. cit., p. 227.

${ }^{99}$ POLETTI, Ronaldo. Op. cit., p. 80.

${ }^{100}$ MENDES, Gilmar Ferreira. Op. cit., p. 1096.

${ }^{101}$ BARROSO, Luís Roberto. Op. cit., p. 85-86.

${ }^{102}$ CLEVE, Clèmerson Merlin. Op. cit., p. 68.
} 
Manteve o controle de constitucionalidade adotado em 1891, mas retrocedeu quanto à maioria das conquistas da Constituição de 1934. Reproduziu a exigência do quorum qualificado para declaração de inconstitucionalidade pelos Tribunais, mas excluiu do ordenamento jurídico a Representação Interventiva e a possibilidade de suspensão, pelo Legislativo, da execução de lei declarada inconstitucional. ${ }^{103}$

Ademais, na tentativa de limitar a intervenção do judiciário nas leis, sob a justificativa de "viabilizar o equilíbrio e a harmonia entre os poderes", criou a possibilidade de o Presidente submeter a lei declarada inconstitucional pelo Judiciário, caso entenda ser necessária ao bem estar do povo, à promoção ou defesa do interesse nacional, a novo exame do Parlamento, que poderá sustar o efeito da decisão jurisdicional. Essa nova medida implicava no desproporcional fortalecimento do Executivo. ${ }^{104}$

\subsubsection{Constituição de 1946}

A Constituição de 1946 restaurou a democracia e a tradição Republicana do controle de constitucionalidade. Manteve as inovações advindas da Carta de 1891, trouxe de volta ao texto constitucional as inovações adotadas na Carta de 1934 e retirou a possibilidade de o Presidente submeter a lei declarada inconstitucional pelo judiciário à nova apreciação pelo Parlamento, novidade prevista na Carta de $1937 .^{105}$

A nova Constituição aperfeiçoou o mecanismo de fiscalização das leis. Deixou claro, por exemplo, que o Senado Federal era competente para suspender a execução das leis declaradas inconstitucionais em decisão

\footnotetext{
${ }^{103}$ CLEVE, Clèmerson Merlin. Op. cit., p. 68.

${ }^{104}$ LENZA, Pedro. Op. cit., p. 228.

${ }^{105}$ CLEVE, Clèmerson Merlin. Op. cit., p. 69.
} 
definitiva do Supremo Tribunal Federal. Ou seja, as leis declaradas inconstitucionais pelos demais órgãos judiciários não seriam passíveis de suspensão pelo Legislativo. ${ }^{106}$

A Representação Interventiva de 1934, não adotada pela Carta de 1937 e trazida de volta pela Constituição de 1946, ganhou nova configuração com a Emenda Constitucional $\mathrm{n}^{\circ} 16$, de 1965 . Se, originalmente, a Representação Interventiva tinha por fundamento exclusivo a análise da incompatibilidade de norma estadual em face da Constituição Federal, após a Emenda n ${ }^{\circ} 16$ esta ação direta teve seu objeto ampliado.

Admitiu-se a competência do STF para conhecer e julgar a Representação de Inconstitucionalidade de lei ou ato normativo estadual ou federal. Assim, a Representação desvinculou-se da Intervenção Federal, surgindo o instituto da Representação Genérica de Inconstitucionalidade. Importante observar que a legitimidade ativa continuou sendo exclusiva do Procurador-Geral da República. ${ }^{107}$

A Emenda também inovou ao autorizar que o Estado-membro institua a Representação de Inconstitucionalidade em âmbito estadual, de competência do Tribunal de Justiça do Estado, tendo como parâmetro a Constituição Estadual, e como objeto leis ou atos normativos estaduais e municipais. ${ }^{108}$

Há de se deixar claro que a Representação Interventiva não se confunde com a Representação Genérica de Inconstitucionalidade. Enquanto aquela implica o controle concreto de constitucionalidade por via de ação direta, esta implica o controle abstrato de constitucionalidade, isto é, afere e verifica a compatibilidade em tese das leis frente à Constituição. Sobre o assunto, ensina

\footnotetext{
${ }^{106}$ POLETTI, Ronaldo. Op. cit., p. 83.

${ }^{107}$ POLETTI, Ronaldo. Op. cit., p. 84.

${ }^{108}$ MENDES, Gilmar Ferreira. Op. cit., p. 1104.
} 
Poletti:

"Na declaração em tese, a suspensão redunda na ab-rogação da lei ou na derrogação dos dispositivos alcançados, Não cabendo ao órgão legiferante censurado senão a atribuição meramente formal de modificá-la ou regê-la, segundo as diretrizes do prejulgado; é uma inconstitucionalidade declarada erga omnes, e não somente entre as partes; a lei não foi arredada apenas em concreto; foi cessada para todos os efeitos". 109

A Constituição de 1946 representou um enorme avanço para a doutrina brasileira, que acabou desaguando no atual sistema de controle de constitucionalidade brasileiro. Enquanto desde a Lei Fundamental de 1891 até a de 1937 notamos a forte influência do controle jurisdicional difuso norteamericano, a partir de 1946 nos aproximamos do modelo austríaco de controle ao adotarmos no sistema brasileiro também o controle concentrado de constitucionalidade.

\subsubsection{Constituição de 1967}

A Constituição de 1967 manteve quase todos os avanços do sistema de fiscalização de constitucionalidade. Entretanto, não autorizou a instauração da Representação de Inconstitucionalidade em âmbito estadual, o que foi autorizado pela Emenda $\mathrm{n}^{\circ} 1$, de 1969, para que a fiscalização da constitucionalidade da lei municipal também ocorresse em face dos princípios sensíveis da Constituição Estadual. ${ }^{110}$

A Emenda $\mathrm{n}^{\circ}$, de 1977, trouxe grandes inovações, dentre elas a possibilidade da Representação versar sobre a interpretação da lei. Assim, a Representação Genérica de Inconstitucionalidade, de legitimidade do

\footnotetext{
${ }^{109}$ POLETTI, Ronaldo. Op. cit., p. 85.

${ }^{110}$ CLEVE, Clèmerson Merlin. Op. cit., p. 71.
} 
Procurador-Geral da República e de competência do STF, pode ter por fundamento a inconstitucionalidade ou a interpretação de lei ou ato normativo federal ou estadual (art. 119, I, XXX, 1). ${ }^{11}$

\section{2 - A Constituição de 1988}

A Constituição atualmente em vigor confirmou o sistema brasileiro de controle jurisdicional que vinha se desenvolvendo desde a Carta de 1891. Consolidou um sistema fruto da combinação do modelo difuso-incidental com o modelo concentrado-principal e o aperfeiçoou. ${ }^{112}$

A nova Carta ampliou a legitimação ativa para a propositura da ação direta de inconstitucionalidade (antiga Representação Genérica), antes monopólio do Procurador-Geral da República, ${ }^{113}$ estendendo-a a dez titulares (art. 103, incisos).

A ampliação no rol de legitimados fortaleceu o controle concentrado, ao gerar um aumento exponencial na quantidade de ações diretas propostas. A mudança também foi qualitativa, pois assegurou uma maior capacidade de fiscalização dos atos públicos e permitiu que mais questões sobre constitucionalidade de leis e atos normativos fossem diretamente apreciados pelo STF. ${ }^{114}$

Também autorizou os estados-membros a criarem a ADI em âmbito estadual, de competência do Tribunal de Justiça do respectivo estado, tendo por objeto leis e atos normativos estaduais ou municipais, e por parâmetro a Constituição Estadual. ${ }^{115}$

\footnotetext{
${ }^{111}$ MENDES, Gilmar Ferreira. Op. cit., p. 1105.

112 BARROSO, Luís Roberto. Op. cit., p. 87.

${ }^{113}$ LENZA, Pedro. Op. cit., p. 229.

${ }_{114}^{14}$ POLETTI, Ronaldo. Op. cit., p. 92.

${ }^{115}$ CLEVE, Clèmerson Merlin. Op. cit., p. 72.
} 
Outra novidade para o controle concentrado trazida na Constituição de 1988 foi a Ação Direta de Inconstitucionalidade por Omissão. A ADO, como o próprio nome deixa claro, é o instrumento adequando para sanar uma inconstitucionalidade por omissão, que ocorre quando não existe norma infraconstitucional regulamentadora capaz de tornar efetiva a norma constitucional. Ocorre, portanto, devido à omissão do Poder competente, legislativo ou administrativo. ${ }^{116}$

A Constituição também passou a exigir a manifestação do Advogado Geral da União nas ações diretas para que este defenda a norma impugnada quando for apreciada sua inconstitucionalidade; e a manifestação do Procurador-Geral da República em todas as ações diretas e demais ações de competência do STF. ${ }^{117}$

A Representação do PGR tendo por fundamento a interpretação de lei ou ato normativo federal ou estadual foi extinta. Manteve-se a reserva de plenário e a possibilidade de suspensão, pelo Senado, de lei ou ato normativo declarado inconstitucional. $\mathrm{O}$ recurso extraordinário também foi mantido, mas passou a ter feição unicamente constitucional. ${ }^{118}$

Foi prevista a criação da Arguição de Descumprimento de Preceito Fundamental, dispositivo que só foi regulamentado em 1999, com a Lei ${ }^{\circ}$ 9.882 .

A Ação Declaratória de Constitucionalidade de lei ou ato normativo federal, de competência do Supremo Tribunal Federal não estava prevista no texto original da Constituição. Esta foi uma inovação trazida pela Emenda ${ }^{\circ}$ 3, de 1993, que atribuiu a legitimidade ativa para a propositura desta ação ao Presidente da República, às Mesas do Senado e da Câmara dos Deputados e ao

\footnotetext{
${ }^{116}$ POLETTI, Ronaldo. Op. cit., p. 93.

${ }_{117}$ CLEVE, Clèmerson Merlin. Op. cit., p. 72.

${ }^{118}$ MENDES, Gilmar Ferreira. Op. cit., p. 1112-1113.
} 
PGR. ${ }^{119}$

A Emenda Constitucional $\mathrm{n}^{\circ} 45$, de 2004, conhecida como a Reforma do Judiciário, ampliou a legitimidade da ADC aos mesmos legitimados para a propositura da Ação Direta de Inconstitucionalidade. Esta também trouxe novidade para a ADI, estendendo a ela o efeito vinculante antes previsto de maneira expressa somente para a Ação Declaratória de Constitucionalidade. ${ }^{120}$

Podemos observar que a Constituição de 1988, apesar de assegurar os critérios difuso e concentrado de controle, certamente deu mais ênfase a este último, tanto por conta da ampliação do rol de legitimados para a propositura da Ação Direita de Inconstitucionalidade quando pela ampliação do número de ações próprias do controle concentrado. ${ }^{121}$

A redação original da Carta de 88 nos deu quatro tipos de ações de controle concentrado: a Ação Direta de Inconstitucionalidade, A Ação Direta de Inconstitucionalidade por Omissão, a Ação Direta Interventiva e a Arguição de Descumprimento de Preceito Fundamental. A Ação Declaratória de Constitucionalidade só adveio com a Emenda n 3, de 1993, conforme acima mencionado.

Enquanto a Lei $\mathrm{n}^{\circ}$ 9.882, de 1999, regulamentou o procedimento da Arguição de Descumprimento de Preceito Fundamental, a Lei $n^{\circ}$ 9.868, publicada um pouco antes no mesmo ano, disciplinou o processo e julgamento da Ação Direta de Inconstitucionalidade e da Ação Declaratória de Constitucionalidade. ${ }^{122}$

\subsection{Controle de Constitucionalidade via Ação Direta: ADI, ADC e ADO.}

\footnotetext{
${ }^{119}$ CLEVE, Clèmerson Merlin. Op. cit., p. 72.

${ }^{120}$ LENZA, Pedro. Op. cit., p. 229.

${ }^{121}$ BARROSO, Luís Roberto. Op. cit., p. 90.
} 
Conforme estudado, o controle de constitucionalidade brasileiro via ação direta teve seu início com a introdução da Representação Interventiva pela Constituição Republicana de 1934. Contudo, foi a partir da introdução da Ação Genérica de Inconstitucionalidade pela Emenda Constitucional no 16 de 1965 que o controle pela via principal ganhou ênfase no sistema jurídico.

No presente trabalho escolhemos estudar a ação direta de inconstitucionalidade, a ação declaratória de constitucionalidade e a ação direta de inconstitucionalidade por omissão, por serem as ações diretas por excelência, de fiscalização abstrata, cuja questão principal é a discussão acerca da constitucionalidade de lei ou ato normativo. ${ }^{123}$

Enquanto o controle incidental de constitucionalidade ocorre no bojo de um processo e surge como questão prejudicial a ser enfrentada antes da a resolução do litígio no caso concreto, o controle via principal ocorre em ação autônoma, chamada Ação Direta, cuja questão constitucional é o objeto principal. Aqui, não há lide, não há partes. Falamos aqui em um controle abstrato, em tese, que tem por objetivo principal a guarda da supremacia da constituição.

As ações diretas são inerentes ao controle concentrado, cuja origem reside no modelo austríaco. Falamos em concentrado pois a competência para o controle é privativa de um ou um número limitado de órgãos. No caso do Brasil, é o Supremo Tribunal Federal que detém essa competência no âmbito federal, ou seja, é o guardião da Constituição Federal. Por sua vez, no âmbito estadual, i.e., tendo por paradigma a Constituição Estadual, a competência é dos Tribunais de Justiça. ${ }^{124}$

\footnotetext{
${ }^{122}$ BARROSO, Luís Roberto. Op. cit., p. 89.

${ }^{123}$ BARROSO, Luís Roberto. Op. cit., p. 179.

${ }^{124}$ BARROSO, Luís Roberto. Op. cit., p. 182.
} 


\subsubsection{Ação Direta de Inconstitucionalidade (ADI)}

A Ação Direta de Inconstitucionalidade, antes denominada Representação Genérica de Inconstitucionalidade, foi introduzida, conforme mencionado, pela EC 16/65. Nos termos do art. 102, inciso I, "a", compete ao Supremo Tribunal Federal processar e julgar, originariamente, a ADI. A Constituição também autoriza expressamente (art. 125, §2) a instituição de representação de inconstitucionalidade no âmbito estadual, cuja competência lógica é do Tribunal de Justiça.

Quanto à legitimação, e isso vale para as demais ações diretas aqui estudadas, não falamos em partes, sendo mais correto a utilização dos termos "requerente" e "requerido". O motivo, já mencionado acima, é o fato do controle pela via principal não derivar de um litígio, de um caso concreto, consistindo em uma direta apreciação da constitucionalidade da norma em tese. $^{125}$

A legitimação passiva recai sobre as pessoas ou órgãos responsáveis pela edição da norma impugnada. A defesa, entretanto, cabe precipuamente ao Advogado Geral da União, que atua como defensor legis.

Já a legitimação ativa, que originalmente pertencia privativamente ao Procurador-Geral da República, teve com a Constituição de 1988, seu rol expressivamente ampliado, vide incisos do art. 103 da Carta Magna.

Cabe diferenciarmos os legitimados universais dos legitimados especiais. Enquanto aqueles podem atuar na defesa da Constituição em qualquer hipótese, estes precisam comprovar sua ligação (ou a de seus filiados) com a norma objeto da ação. São legitimados universais o Presidente da República, as Mesas da Câmara dos Deputados e do Senado Federal, o

\footnotetext{
${ }^{125}$ BARROSO, Luís Roberto. Op. cit., p. 185-186.
} 
Procurador Geral da República, partidos políticos com representação no Congresso Nacional e o Conselho Federal da OAB. São especiais a Mesa da Assembleia Legislativa ou da Câmara Legislativa do Distrito Federal, Governador de Estado ou do Distrito Federal, Entidades de Classe de âmbito Nacional e as Confederações Sindicais. ${ }^{126}$

Ainda acerca da atuação em ADI, deve o Procurador Geral da República ser citado para manifestar-se sobre o objeto impugnado. Ele atua como custus legis, i.e., fiscal da lei. A Lei 9868 de 1999 trouxe a possibilidade de manifestação do amicus curiae, órgãos ou entidades que possuam algum interesse no julgamento da lide. ${ }^{127}$

Os objetos da ADI são leis ou atos normativos estaduais ou federais. Exigia-se pela jurisprudência que a norma impugnada fosse dotada de generalidade e abstração, mas essa limitação começou a ser atenuada. Hoje o requisito de conteúdo abstrato já foi afastado pela jurisprudência em 2008, quando foi dito que o caráter abstrato derivava do fato da questão constitucional ser posta em tese, desvinculada de caso concreto. ${ }^{128}$

São passíveis de apreciação em ADI a emenda constitucional, a lei ordinária, a lei complementar, a lei delegada, a medida provisória, o decreto legislativo e a resolução do Congresso, o decreto autônomo, o decreto (legislativo e executivo) que internaliza tratado e a legislação estadual, incluindo nessa última hipótese as Constituições dos estados-membros.

O que todas essas hipóteses de objeto têm em comum é o fato de serem atos primários, federais ou estaduais, que inovam na ordem jurídica. A contrario sensu, não são impugnáveis via ADI atos normativos secundários (que apenas regulamentam um ato primário sem inovar), atos de efeitos

\footnotetext{
${ }^{126}$ BARROSO, Luís Roberto. Op. cit., p. 187-196.

${ }^{127}$ BARROSO, Luís Roberto. Op. cit., p. 197.

${ }^{128}$ BARROSO, Luís Roberto. Op. cit., p. 198-211.
} 
concretos, atos pré-constitucionais atos revogados, projetos de lei e leis municipais.

\subsubsection{Ação Declaratória de Constitucionalidade (ADC)}

Criada pela Emenda Constitucional 3 de 1993 à Carta de 1988, visa pacificar controvérsia judicial relevante acerca da constitucionalidade de lei ou ato normativo federal, de forma a afastar a incerteza jurídica que paira nas relações jurídicas cuja norma incide. ${ }^{129}$

A competência é a mesma da ADI, ou seja, do STF. Apesar de não haver previsão expressa, a doutrina majoritária, com fundamento, dentre outros, na autonomia dos estados-membros, tem admitido a criação de ADC em âmbito estadual, tendo por objeto leis e atos municipais e estaduais, cuja competência será do Tribunal de Justiça do respectivo estado. ${ }^{130}$

A ADC nasceu tendo por legitimados ativos o Presidente da República, as Mesas do Senado e da Câmara dos Deputados e o PGR. Com a Emenda Constitucional 45 de 2004, conhecida como Reforma do Judiciário, passou a ter os mesmos legitimados da ADI, nos termos da nova redação do caput do art. $103 \mathrm{CRFB} / 88$.

Exige-se a manifestação do Procurador Geral da República, que atuará como custos legis. Entretanto, não haverá citação do Advogado Geral da União, que na ADI atua como defensor legis, visto que o que se pretende com a ADC é justamente a declaração de constitucionalidade. ${ }^{131}$

O objeto, conforme supracitado, é a lei ou ato normativo federal. Os tipos normativos que podem ter sua constitucionalidade declarada via ADC são

\footnotetext{
${ }^{129}$ BARROSO, Luís Roberto. Op. cit., p. 258.

${ }^{130}$ BARROSO, Luís Roberto. Op. cit., p. 260-261.

${ }^{131}$ BARROSO, Luís Roberto. Op. cit., p. 263.
} 
os mesmos da ADI, exceto leis estaduais. Vale lembrar que a existência de controvérsia judicial relevante é requisito essencial para a propositura da ação. Esta já era uma existência da jurisprudência que foi pacificada com a promulgação da Lei 9.868 de $99 .{ }^{132}$

\subsubsection{Ação Direta de Inconstitucionalidade por Omissão (ADO)}

A Ação Direta de Inconstitucionalidade por Omissão foi introduzida no sistema jurídico brasileiro pela Constituição de 1988 , em seu art. $103, \S 2^{\circ}$. A inconstitucionalidade por omissão deriva da inércia ilegítima do poder legiferante, que se omitiu no seu dever de legislar. Em regra, essa é uma faculdade discricionária do legislador, mas há casos em que a Constituição impõe uma atuação positiva, pois é necessária a edição de norma que efetive um mandamento constitucional. ${ }^{133}$

Bem verdade, a omissão constitucional pode ser imputada ao legislativo, na falta de edição de norma primária, mas também ao executivo, na omissão de edição de norma secundária de caráter geral.

Aqui, ao contrário do que ocorre na $\mathrm{ADI}$ e na $\mathrm{ADC}$, não haverá uma norma objeto de impugnação. Isso, pois, como dito em capítulo anterior, a inconstitucionalidade reside justamente na inexistência de norma infraconstitucional (lacuna normativa). Pode, entretanto, haver uma inconstitucionalidade por omissão parcial, isto é, há a norma, mas ela é insuficiente ou insatisfatória. Nesse último caso, o objeto da ação será a norma eivada de parcial vício. ${ }^{134}$

A omissão deverá ser de caráter normativo, e aqui abrangemos

\footnotetext{
${ }^{132}$ BARROSO, Luís Roberto. Op. cit., p. 263-264.

${ }^{133}$ BARROSO, Luís Roberto. Op. cit., p. 280.

${ }^{134}$ BARROSO, Luís Roberto. Op. cit., p. 286-288.
} 
certamente atos gerais, abstratos e obrigatórios de outros Poderes além do Legislativo. O objeto da ADC comporta tanto o objeto da ADI, qual seja atos normativos primários, quanto atos normativos secundários, de competência do Executivo ou mesmo de órgãos do judiciário.

A competência em âmbito federal, assim como todas as demais Ações Diretas, é do STF. A doutrina vem admitindo, apesar de inexistente previsão expressa, a criação de ADO em âmbito estadual, novamente tendo por competente para seu processo e julgamento o Tribunal de Justiça dos estados, e por parâmetro a Constituição Estadual. ${ }^{135}$

Os legitimados ativos são os mesmos da ADI e da ADC. A legitimidade passiva incide sobre o agente ou órgão responsável pela norma exigida pela Constituição e não editada.

Enquanto na ADI visa-se a declaração de inconstitucionalidade, e na ADC a declaração de constitucionalidade, na $\mathrm{ADO}$ a providência requerida dependerá do legitimado passivo. Se for um dos Poderes o sujeito passivo, o pedido limitar-se-á a que seja dada ciência da omissão inconstitucional, para que sejam adotadas as devidas providências. A decisão, na realidade, não obrigará o poder omisso a agir. ${ }^{136}$

Por outro lado, caso a omissão seja imputável a um órgão administrativo, o pedido e, em caso de deferimento, a decisão será revestida de caráter impositivo, uma verdadeira ordem para que se adote as medidas necessárias a sanar a inconstitucionalidade no prazo de 30 dias, sob pena de responsabilização.

O STF tem admitido, desde 2010, relativa fungibilidade entre as ações diretas de inconstitucionalidade por ação e por omissão. Obviamente isso só é

\footnotetext{
${ }^{135}$ BARROSO, Luís Roberto. Op. cit., p. 282.

${ }^{136}$ BARROSO, Luís Roberto. Op. cit., p. 294-296.
} 
possível no caso de omissão parcial, e se justifica na medida em que uma omissão parcial não deixa de ser uma ação incompatível com a Constituição. ${ }^{137}$

${ }^{137}$ BARROSO, Luís Roberto. Op. cit., p. 300. 


\section{Efeitos da Declaração de Inconstitucionalidade em Ações Diretas do Controle De Constitucionalidade Brasileiro}

Os efeitos da declaração de inconstitucionalidade em Ação Direta são, em regra, retroativos (ex tunc), gerais (erga omnes), repristinatórios e vinculantes. Esse é o entendimento majoritário doutrinário e jurisprudencial que foi ratificado com a edição da Lei $9.868 / 99$ que trata do processamento e julgamento da ADI, ADC e ADO.

No presente capítulo estudaremos o objeto em específico de nossa monografia. Veremos os efeitos que geralmente decorrem da declaração de inconstitucionalidade e também a mitigação desses, chamada modulação de efeitos, que tem ganhado cada vez mais espaço nas decisões em Ações Diretas.

\subsection{Efeitos objetivos}

A decisão que reconhece a inconstitucionalidade, conforme estudado, possui natureza declaratória, reconhecendo e dando certeza jurídica a situação preexistente de invalidade da norma por vício de inconstitucionalidade. A inconstitucionalidade, que afeta diretamente o plano da validade da norma, repercute no plano da eficácia, afinal, lei ou ato nulo não podem produzir efeitos.

Observamos, portanto, que o plano da existência da norma não é afetado formalmente. Apesar disso, considerando que a vigência da norma é a soma de sua existência com sua eficácia, concluímos que a lei declarada inconstitucional deixa de vigorar. ${ }^{138}$

Contudo, é válido aqui mencionar o posicionamento de Teori Zavascki,

\footnotetext{
${ }^{138}$ BARROSO, Luís Roberto. Op. cit., p. 228-229.
} 
segundo o qual o vício de inconstitucionalidade, ao acarretar a nulidade da norma, a exclui do ordenamento jurídico. ${ }^{139}$ A esse entendimento, soma-se a jurisprudência do STF:

“a declaração de inconstitucionalidade em tese encerra um juízo de exclusão, que, fundado numa competência de rejeição deferida ao STF, consiste em remover do ordenamento positivo a manifestação estatal inválida e desconforme ao modelo plasmado na Carta Política". ${ }^{140}$

Parece-nos a melhor doutrina aquela que entende ser um dos efeitos objetivos da decisão de inconstitucionalidade a perda de vigência da norma, vez que formalmente seu plano de existência não é afetado, não sendo a norma eliminada formalmente do ordenamento jurídico, apesar de, de fato, ter a mesma consequência que teria se tivesse sido revogada.

Outro efeito objetivo da declaração de inconstitucionalidade é o efeito repristinatório. Esse efeito faz com que a declaração de inconstitucionalidade de uma norma repercuta na legislação anterior por ela revogada. Explica Barroso:

"Se a lei revogadora vier a ser declarada inconstitucional, não deverá produzir efeitos válidos, impondo o princípio da Supremacia da Constituição que a situação jurídica volte ao status quo ante". ${ }^{141}$

Por esse efeito, defendido pela jurisprudência e doutrina e ratificado pela Lei n 9.868/99, a declaração de inconstitucionalidade de uma lei restaura a vigência da legislação previamente existente por ela afetada. Pode, entretanto, o STF manifestar-se expressamente em sentido contrário.

\subsection{Efeitos subjetivos}

${ }^{139}$ ZAVASCKI, Teori Albino. Op. cit., p. 62.

${ }^{140}$ STF, Pleno, ADI 652-5, re. Min. Celso de Mello, RTJ 146/461. 
A eficácia da decisão de inconstitucionalidade nas Ações Diretas é contra todos, erga omnes. Tal efeito subjetivo explica-se pela substituição processual: os legitimados para a propositura da ação (art. 103, incisos) atuam com legitimação extraordinária, i.e, em nome próprio na defesa de direitos difusos, de interesse de toda a coletividade.

Ademais, sabe-se que as Ações Diretas não possuem partes por não se tratar da resolução de uma lide em um caso concreto. Os termos corretos são requerente e requerido. Por essas duas razões não há de se falar em efeitos inter partes, e sim em efeitos em erga omnes.

O artigo 28 da Lei 9868/99 dispõe:

"a declaração de constitucionalidade ou inconstitucionalidade, inclusive a interpretação conforme a Constituição e a declaração parcial de inconstitucionalidade sem redução de texto têm eficácia contra todos e efeito vinculante em relação aos órgãos do Poder Judiciário e à Administração Pública federal, estadual e municipal".

Desse dispositivo extraímos o segundo efeito subjetivo, qual seja o efeito vinculativo da declaração de inconstitucionalidade. O efeito vinculante obriga os órgãos do Poder Judiciário e a Administração Pública a adotarem a tese jurídica firmada pelo STF sempre que a ela a decisão da causa esteja logicamente subordinada. Ensina Teori Zavaski: ${ }^{142}$

“o efeito vinculante confere ao julgado uma força obrigatória qualificada em relação a supervenientes atos administrativos ou judiciais, com a consequência processual de assegurar, em caso de recalcitrância, a utilização de um mecanismo executivo próprio - a reclamação - para impor o seu cumprimento".

${ }^{141}$ BARROSO, Luís Roberto. Op. cit., p. 229.

${ }^{142}$ ZAVASCKI, Teori Albino. Op. cit., p. 64. 
Esse efeito incide sobre todos os órgãos do Poder Judiciário, inclusive sobre o próprio STF. Vincula também a administração pública federal, estadual e municipal. Já o poder legislativo, na sua função legislativa, foi excluído do alcance vinculante, o que significa a possibilidade de ser criada nova norma sobre a matéria que incorra na mesma inconstitucionalidade. Caberá, nesse caso, a propositura de nova Ação Direta. ${ }^{143}$

O legislador, no mesmo dispositivo infraconstitucional, atribuiu também

efeitos vinculantes à declaração parcial de inconstitucionalidade e à interpretação conforme a constituição, possibilidades de decisão no controle via principal que serão a seguir estudadas.

\subsection{Efeito transcendente}

O efeito vinculante, conforme a tradição do direito processual civil (art. 469, I), limita-se à parte dispositiva da decisão judicial, não atingindo nem a fundamentação e tampouco o relatório.

Apesar dessa regra, o Supremo Tribunal Federal tem ampliado a incidência do efeito vinculante nas decisões proferidas em sede de controle abstrato de constitucionalidade, com base na transcendência dos motivos determinantes. Significa que o efeito vinculante passa a abarcar não só a parte dispositiva, mas também os fundamentos que levaram à decisão. ${ }^{144}$

A consequência dos efeitos transcendentes é que os órgãos do Judiciário e a Administração Pública devem deferência não só ao que foi decido, mas também aos argumentos e interpretações que embasaram a decisão.

\subsection{Efeito repristinatório}

\footnotetext{
${ }^{143}$ BARROSO, Luís Roberto. Op. cit., p. 230-231.

${ }^{144}$ BARROSO, Luís Roberto. Op. cit., p. 235-236.
} 
Apesar da Lei n 9.868/99 só ter feito previsão de efeito repristinatório quanto à concessão de cautelar em ADI (art. 11, §2o), o entendimento doutrinário e jurisprudencial é de que se aplica também às decisões finais de inconstitucionalidade em Ações Diretas.

Ao ser declarada a inconstitucionalidade de uma norma, restaura-se a norma anterior por ela revogada. Se fosse diferente, estar-se-ia admitindo que a norma inconstitucional, inválida, produziu efeitos. Não obstante, pode a Suprema Corte dispor expressamente em contrário, em juízo de conveniência e oportunidade ou por entender que a norma a ser restaurada também padece do vício de inconstitucionalidade. ${ }^{145}$

\subsection{Efeitos temporais e modulação de efeitos}

O Brasil adotou a teoria da nulidade da norma inconstitucional. Conforme visto em tópicos anteriores, de acordo com essa teoria a norma inconstitucional padece de nulidade absoluta e consequente ineficácia plena. Nesse sentido, a norma inconstitucional é nula em si mesma, desde sua origem, natimorta.

A teoria da nulidade que, a princípio, era aplicada ao controle difuso, com a evolução da fiscalização de constitucionalidade e a adoção, pelo Brasil, também do controle concentrado, passou a incidir nas decisões do Supremo Tribunal Federal, consolidando a nulidade originária da lei inconstitucional e a consequente retroatividade - efeitos ex tunc - dessas decisões.

A decisão do STF limitar-se-á a declarar uma situação preexistente, estabelecendo acerca dela uma certeza jurídica. $\mathrm{O}$ efeito retroativo se justifica,

\footnotetext{
${ }^{145}$ BARROSO, Luís Roberto. Op. cit., p. 242-243.
} 
pois se o vício é congênito à lei (situação preexistente), os efeitos da declaração de inconstitucionalidade haverão de retroagir a data de ingresso da norma no mundo jurídico. ${ }^{146}$

A opção do sistema brasileiro pela teoria da nulidade se deu, em grande medida, devido à influência do sistema de controle norte-americano, estudado no capítulo 3. Não obstante, a jurisprudência do STF atenuou a posição radical desta teoria, tornando-a mais maleável e permitindo exceções em que a decisão não deveria produzir efeitos retroativos. Aplicou, em certa medida e em certos casos, conceitos da tese da anulabilidade na decisão de inconstitucionalidade. ${ }^{147}$

Em deferência à boa solução jurisprudencial, o legislador autorizou expressamente, no art. 27 da Lei n 9.868/99, que seja feita a modulação dos efeitos temporais pelo Supremo Tribunal Federal. In verbis:

"Art. 27. Ao declarar a inconstitucionalidade de lei ou ato normativo, e tendo em vista razões de segurança jurídica ou de excepcional interesse social, poderá o Supremo Tribunal Federal, por maioria de dois terços de seus membros, restringir os efeitos daquela declaração ou decidir que ela só tenha eficácia a partir de seu trânsito em julgado ou de outro momento que venha a ser fixado".

O dispositivo inovou no sistema de controle brasileiro ao permitir que o Supremo restrinja os efeitos da decisão a determinada categoria de pessoas; e que ele não atribua efeito ex tunc à declaração de inconstitucionalidade, fazendo-a incidir a partir do trânsito em julgado da decisão ou de determinada data no futuro.

Luís Roberto Barroso destaca que houve a formalização de um mecanismo de ponderação de valores, mas deixa claro que não estamos ponderando a Supremacia da Constituição, fundamento da existência do controle de constitucionalidade, mas ponderando a norma violada e outras

\footnotetext{
${ }^{146}$ BARROSO, Luís Roberto. Op. cit., p. 236-237.

${ }^{147}$ BARROSO, Luís Roberto. Op. cit., p. 42.
} 
normas constitucionais, tais quais a boa-fé, coisa julgada, razoabilidade, etc. ${ }^{148}$

Teori Zavaski diferencia a eficácia normativa da eficácia executiva nas decisões de inconstitucionalidade. Entende que a eficácia normativa é a que se opera no plano do ordenamento jurídico, i.e, que diz respeito à invalidade da norma e à sua exclusão do ordenamento jurídico. Já a eficácia executiva diz respeito às consequências da decisão no plano da realidade prática, ou seja, a consequência que a invalidade da norma gerará aos seus destinatários.

Assim, no seu entendimento, a eficácia normativa gera efeitos ex tunc, enquanto a eficácia executiva efeitos prospectivos. Considera, portanto, a modulação de efeitos "a limitação da força executiva da sentença declaratória de inconstitucionalidade" e, portanto, que "os efeitos que modulam são os que se operam no campo prático, concreto, no plano dos comportamentos, e não no plano do ordenamento jurídico". ${ }^{149}$

A seguir, estudaremos, primeiramente, as decisões de nulidade da norma inconstitucional, cujos efeitos temporais retroagirão à data em que a norma entrou em vigor. Apesar dos efeitos ex tunc serem regra no controle brasileiro de constitucionalidade pela via principal, não foram poucas as possibilidades de mitigação a esse efeito criadas pela jurisprudência da Suprema Corte. Assim, seguiremos e finalizaremos com a análise de cada uma das espécies de modulação de efeitos.

\subsubsection{Declaração De Nulidade Total}

A declaração de nulidade total ocorre quando toda a lei ou ato normativo é invalidado pelo órgão julgador, isto é, quando não há como desmembrar em uma parte válida e outra inválida.

\footnotetext{
${ }^{148}$ BARROSO, Luís Roberto. Op. cit., p. 239-233.
} 
Ocorre, geralmente, em casos de inconstitucionalidade formal, seja orgânica - inobservância da competência legislativa -, seja propriamente dita quando há vício de iniciativa (vício subjetivo) ou nas demais fases do processo legislativo (vício objetivo). ${ }^{150}$ Referimo-nos aqui à declaração de nulidade total como expressão de unidade técnico-legislativa. ${ }^{151}$

A jurisprudência do Supremo Tribunal Federal possui vários julgados declarando a nulidade total de leis e atos normativos que ferem as regras de iniciativa e às normas constitucionais de repartição de competência. Nesse sentido, a ADI 3323 DF de relatoria do Min. Joaquim Barbosa que, em seu voto, declarou:

“[...] A invasão da competência legislativa da União me basta para considerar inconstitucional a norma ora atacada. Com essas breves considerações, julgo procedente o pedido, para declarar a inconstitucionalidade da Lei 3.425 , de 04.08.2004, do Distrito Federal”.

Pode ocorrer ainda que a lei não seja em sua totalidade viciada, mas a dependência de um dispositivo por si constitucional em relação a dispositivo declarado inconstitucional irá fomentar a declaração de nulidade total. O mesmo ocorrerá se houver interdependência entre dispositivo declarado inconstitucional e dispositivo sem qualquer vício. Aqui, ocorre a declaração de nulidade total devido à dependência ou interdependência entre as partes constitucionais e inconstitucionais da lei. Assim, o acórdão da Rp 1379, rel. Min. Moreira Alves:

REPRESENTAÇÃO DE INCONSTITUCIONALIDADE. SISTEMA DUPLO DE VENCIMENTOS E DE VANTAGENS PARA A MAGISTRATURA DA MESMA CARREIRA É INCONSTITUCIONAL. No caso, declara-se a inconstitucionalidade

\footnotetext{
${ }^{149}$ ZAVASCKI, Teori Albino. Op. cit., p. 65-66.

${ }^{150}$ LENZA, Pedro. Op. cit., p. 232-233

${ }^{151}$ MENDES, Gilmar Ferreira. Op. cit., p. 1360-1362.
} 
de toda a sistemática, porque a declaração de inconstitucionalidade parcial importaria verdadeira criação de uma lei nova, não votada pelo legislativo, que, presumidamente, não a votaria por afastar-se da orientação que presidiu a sua feitura. Representação que se julga procedente para declarar inconstitucionais os artigos terceiro, quarto (e seu parágrafo único), quinto (e seus parágrafos) e sexto da lei 9.262, de 11 de setembro de 1986, do estado de Minas Gerais. Ressalva quanto ao anexo ii da referida lei. (STF - Rp: 1379 MG , Relator: MOREIRA ALVES, Data de Julgamento: 12/08/1987, TRIBUNAL PLENO, Data de Publicação: DJ 11-09-1987 PP-18988 EMENT VOL-01473-01 PP-00068) - (grifo nosso).

$\mathrm{Na}$ declaração de nulidade total por dependência ou interdependência surge a possibilidade de declaração de inconstitucionalidade por arrastamento/por atração, também denominada de inconstitucionalidade consequente de preceitos não impugnados. Isto é, pode uma norma impugnada ser declarada inconstitucional e, consequentemente, outra norma que dependa daquela ser também julgada inconstitucional, ainda que não impugnada no pedido inicial da ação.

Interessante notar que essa técnica de inconstitucionalidade por arrastamento é possível tanto em processos distintos quanto no mesmo processo. Pode ocorrer, ainda, em relação a decreto que se fundava em lei inconstitucional. ${ }^{152}$ A exemplo, a ADI 2995/PE, rel. Min. Celso de Mello, que, em seu voto, dispôs:

"[...] julgo procedente a presente ação direta, para declarar a inconstitucionalidade da Lei $\mathrm{n}^{\circ} 12.343$, de 29 de janeiro de 2003, do Estado de Pernambuco, estendendo essa mesma eficácia, ainda, por via de arrastamento, ao Decreto $n^{\circ} 24.446$ [...]”.

\subsubsection{Declaração De Nulidade Parcial}

Se parte da lei for constitucional, e parte inconstitucional, e aquela puder sobreviver no mundo jurídico e manter sua aplicabilidade no mundo dos fatos sem esta, então é perfeitamente possível a declaração de nulidade parcial 
da lei impugnada. Esse é entendimento integralmente aceito na doutrina e na jurisprudência. Assim foi julgado na ADI 2895/AL de relatoria do Min. Carlos Velloso:

CONSTITUCIONAL. ADMINISTRATIVO. SERVIDOR PÚBLICO: REMUNERAÇÃO: VINCULAÇÃO OU EQUIPARAÇÃO. C.F., art. 37, XIII. Lei Complementar $n^{\circ}$ 7, de 1991, com a redação da Lei Complementar $n^{\circ} 23$, de 2002, do Estado de Alagoas. I. - Objetivando impedir majorações de vencimentos em cadeia, a Constituição Federal, art. 37, XIII, veda a vinculação ou equiparação de vencimentos para o efeito de remuneração de pessoal do serviço público. II. Inconstitucionalidade de parte da segunda parte do art. 74 da Lei Complementar $n^{\circ} 7$, de 1991, com a redação da Lei Complementar $n^{\circ}$ 23, de 2002, ambas do Estado de Alagoas. III. - Não obstante de constitucionalidade duvidosa a primeira parte do mencionado artigo 74, ocorre, no caso, a impossibilidade de sua apreciação, em obséquio ao "princípio do pedido" e por não ocorrer, na hipótese, o fenômeno da inconstitucionalidade por "arrastamento" ou "atração", já que o citado dispositivo legal não é dependente da norma declarada inconstitucional. ADI 2.653/MT, Ministro Carlos Velloso, "DJ" de 31.10.2003. IV. - ADI julgada procedente, em parte. (STF - ADI: 2895 AL , Relator: CARLOS VELLOSO, Data de Julgamento: 02/02/2005, Tribunal Pleno, Data de Publicação: DJ 20-05-2005 PP-00005 EMENT VOL-02192-03 PP-00434 LEXSTF v. 27, n. 319, 2005, p. 49-60 RTJ VOL-0019402 PP-00533) - (grifo nosso).

Para que seja possível a declaração de nulidade parcial, imprescindível é analisar a dependência/ interdependência entre os dispositivos em questão. Se for tal que não permita a divisibilidade da norma, haverá declaração de nulidade total. Não obstante, se esta puder ser dividida em parte viciada e não viciada e a não viciada puder subsistir de forma autônoma, então teremos presente o requisito objetivo da divisibilidade. ${ }^{153}$

Entretanto, há de se analisar também o requisito subjetivo, qual seja a vontade do legislador. Ainda que presente a divisibilidade, para que haja a declaração de nulidade parcial, faz-se mister constatar que a norma subsistente corresponde à vontade do legislador ordinário. Assim, se a declaração parcial resultar em criação de nova lei que não reporte a intenção que tinha o

\footnotetext{
${ }^{152}$ LENZA, Pedro. Op. cit., p. 283-284
} 
legislador, não poderemos escapar da declaração de nulidade total ou, ao menos, da nulidade parcial sem redução do texto.

\subsubsection{Declaração De Nulidade Parcial Sem Redução De Texto}

Pode ocorrer que a norma, divisível, que padeça parcialmente de inconstitucionalidade não possa sofrer redução em seu texto, entretanto. Isso, pois a supressão de determinada expressão modificaria a intenção do legislador. Assim, abre-se uma nova possibilidade, de criação jurisprudencial, qual seja a declaração de nulidade parcial sem redução de texto.

Essa declaração é outra das formas de modulação dos efeitos das decisões em controle de constitucionalidade. Amplamente aceita e frequentemente utilizada pelo Supremo Tribunal Federal em seus julgados mesmo antes de 1999, essa técnica foi positivada com a promulgação da Lei 9.868, de 10 de novembro deste ano, que abarcou a possibilidade de restrição dos efeitos e da eficácia destas decisões.

Consiste na constatação de que uma das hipóteses ou interpretações de determinada norma é contrária à Lei Maior e, portanto, não pode ser considerada. Por outro lado, as demais interpretações da norma são perfeitamente válidas e compatíveis com o texto constitucional, motivo pelo qual o texto da norma infraconstitucional merece permanecer vigente, isto é, sem alteração literal, produzindo os seus efeitos, em deferência à presunção de constitucionalidade das normas.

Se, por um lado, pode ser considerada como um dos instrumentos do controle de constitucionalidade, por outro, é também técnica de hermenêutica. A declaração de nulidade parcial sem redução de texto interpreta a norma

\footnotetext{
${ }^{153}$ MENDES, Gilmar Ferreira. Op. cit., p. 1362-1363.
} 
infraconstitucional conforme a Constituição, de forma a retirar do ordenamento jurídico unicamente sua interpretação inconstitucional, mantendo as demais. Como ensina Gilmar Ferreira Mendes, nesses casos o Tribunal limitar-se-á a decretar certa possibilidade de aplicação da lei inconstitucional, sem alterar a expressão literal da lei. ${ }^{154}$

Certamente que essa técnica só poderá incidir em normas polissêmicas, quais sejam aquelas redigidas em linguagem ampla, que possuam mais de um significado, aplicação ou interpretação, possibilitando a "divisão" da norma jurídica em parte constitucional e parte inconstitucional. Em contrapartida, a norma monossêmica que padeça de inconstitucionalidade não deixa outro sentido a ser aproveitado, devendo então ser declarada totalmente inconstitucional e retirada do mundo jurídico.

\subsubsection{Interpretação Conforme A Constituição}

Apesar de, muitas vezes, ser dita sinônimo da declaração de nulidade parcial sem redução de texto, a interpretação conforme a constituição, embora semelhante, não se confunde com aquela. A semelhança decorre de ambas as técnicas serem criações jurisprudenciais de hermenêutica e controle de constitucionalidade que têm por objetivo preservar o texto normativo, prestando deferência ao poder legislativo.

Não obstante, a nosso ver, haver claras distinções entre as duas técnicas tratadas acima, é certo que estas continuam a ser confundidas, tanto na doutrina quanto na jurisprudência, inclusive em se tratando do Supremo Tribunal Federal. Conforme discorre Gilmar Ferreira Mendes, ${ }^{155}$ sobretudo no controle abstrato, a Suprema Corte parecia buscar a equivalência de ambas as

\footnotetext{
${ }^{154}$ MENDES, Gilmar Ferreira. Op. cit., p. 1364.
} 
técnicas. Destaca, entretanto, os problemas entre tal equiparação.

Ao contrário da declaração de nulidade parcial sem redução de texto, que exclui certas hipóteses de aplicação da norma sem subtrair-lhe, contudo, expressão literal, a interpretação conforme a constituição dita expressamente a interpretação que deve ser feita de tal norma para que esteja em consonância com o texto constitucional. Ou seja, enquanto aquela exclui alguma (as) hipótese (s), esta delimita.

Como consequência da utilização de uma ou outra técnica, surge a segunda diferença entre elas: eventual ação direta de inconstitucionalidade (ADI) será julgada procedente, se aplicada a declaração de nulidade parcial sem redução de texto, e será julgada improcedente, se aplicada a interpretação conforme. Assim, naquela a decisão será de procedência, para declarar certa interpretação inconstitucional, enquanto nesta a decisão será de improcedência, para declarar a constitucionalidade da norma contando que interpretada de determinada forma.

No que tange ao efeito vinculante, a declaração de nulidade parcial sem redução de texto obriga a não-aplicação da hipótese declarada inconstitucional, isto é, vincula as atividades judiciais e administrativas, assim como ocorre na declaração de nulidade total e na declaração de nulidade parcial com redução de texto. Ao contrário, a interpretação conforme não produz efeitos vinculantes, da mesma forma que a declaração de constitucionalidade. ${ }^{156}$

Outra discrepância entre as duas técnicas consiste no fato de que a interpretação conforme busca os sentidos constitucionais de aplicação da norma, cumprindo, precipuamente, o papel de instrumento de hermenêutica, enquanto a declaração sem redução de texto busca determinar as hipóteses

\footnotetext{
${ }^{155}$ MENDES, Gilmar Ferreira. Op. cit., p. 1368-1369.

${ }^{156}$ BARROSO, Luís Roberto. Op. cit., p. 234-235.
} 
inconstitucionais da norma, e, em contrapartida, as hipóteses constitucionais, visando, primordialmente, fazer o controle de constitucionalidade normativo.

$\mathrm{Se}$, conforme parecia entender o STF, equiparássemos as duas categorias, o que significaria conceder à interpretação conforme a Constituição, modalidade de interpretação, status de técnica de declaração de inconstitucionalidade, haveria de ser delimitado esse status apenas para as decisões emanadas da Corte Constitucional pois, de outra forma, qualquer interpretação conforme deveria ser submetida ao pleno ou ao órgão especial, conforme os ditames do art. 97 da Constituição Republicana. Dessa forma, diz Gilmar Mendes, ${ }^{157}$ se parece fácil a equiparação no controle abstrato, não o seria no controle concreto e difuso.

Mais recentemente, contudo, o Supremo Tribunal Federal parece estar se afastando de sua orientação anterior de equiparação das duas técnicas, tendendo a dar autonomia à declaração de nulidade parcial sem redução de texto. Uma vez enfrentada a discussão a respeito da conexão e diferenciação entre as técnicas, passemos a dissertar em específico sobre o tema do presente tópico.

Se, por um lado, a interpretação conforme a Constituição vai ao encontro de sua supremacia e busca uma interpretação sistemática entre as normas do ordenamento jurídico, além de prestar respeito àquele que positivou a norma, por outro esbarra em certos limites, quais sejam o texto literal e a própria vontade do legislador. Verdade é que pouco se busca saber a vontade do legislador, contanto que a interpretação não fira a literalidade da norma.

Bem verdade também é que, de todo modo, qualquer interpretação modificará, ainda que minimamente, a vontade daquele que a criou. Assim, faz-se mister a cautela para que o Tribunal não se torne legislador positivo,

\footnotetext{
${ }^{157}$ MENDES, Gilmar Ferreira. Op. cit., p. 1368-1369.
} 
modificando o sentido original do texto. ${ }^{158} \mathrm{O}$ STF adota normalmente uma visão kelseniana restritiva de legislador negativo.

Entretanto, não são raros os casos em que se pode verificar uma alteração no sentido do texto normativo devido à interpretação conforme a Constituição feita pela Suprema Corte, figurando o que a doutrina constitucional chama de decisões manipulativas de efeitos aditivos. Ou seja, o STF acaba atuando como legislador positivo, dando origem ao chamado ativismo judicial. Exemplo é a ADPF 54 sobre aborto de fetos anencéfalos, cuja decisão procedente conferiu interpretação conforme aos arts. 124 e 128 do Código Penal Brasileiro acrescentando, assim, mais uma hipótese de excludente de punibilidade ao crime de aborto. ${ }^{159}$

\subsubsection{Decisões Com Efeitos Aditivos}

A decisão manipulativa é aquela em que o órgão de jurisdição constitucional modifica diretamente a norma submetida ao seu exame de forma a torná-la adequada à Constituição. Essa decisão tem aplicação imediata, não necessitando de quaisquer intervenções do Legislativo.

A decisão manipulativa de efeitos aditivos ocorre quando a corte declara a inconstitucionalidade por omissão de uma norma e expande seu texto ou hipótese de incidência. Visa sanar a omissão inconstitucional do legislador, reparando as lacunas legislativas. A sentença aditiva se faz necessária, levando-se em consideração três fatores:

“a) a existência de uma Carta política de perfil marcadamente programático e destinada a progressivo desenvolvimento; b) a permanência de um ordenamento jurídico-positivo com marcados resquícios autoritários; e c) a ineficácia do legislativo

\footnotetext{
${ }^{158}$ MENDES, Gilmar Ferreira. Op. cit., p. 1370-1371.

${ }^{159}$ MENDES, Gilmar Ferreira. Op. cit., p. 1372.
} 
para responder, em tempo adequado, às exigências de atuação da Constituição e à conformação do ordenamento preexistente ao novo regime constitucional". ${ }^{160}$

Não estamos aqui falando propriamente do ativismo judicial, que ocorre quando há uma atuação legislativa positiva do STF, que inova na ordem jurídica de forma discricionária e por motivos políticos. Entendemos que, ao contrário, a sentença aditiva inova tomando por base critérios objetivos e bem definidos, não havendo ofensa ao princípio da separação de poderes, mas tão somente deferência a outros princípios constitucionais, tais quais segurança jurídica e isonomia.

\subsubsection{Declaração de inconstitucionalidade sem a pronúncia da nulidade}

À parte os casos de omissão total do legislador, que são cada vez mais raros, vemos, na maioria das vezes, uma omissão parcial devido à lacuna na lei, que atende parcialmente ou de forma insuficiente aos ditames constitucionais.

A inconstitucionalidade por omissão parcial exige, via de regra, bem como a inconstitucionalidade por ação, a suspensão da aplicação da norma. Entretanto, em determinados casos, a aplicação da lei, mesmo após a declaração de sua inconstitucionalidade parcial, pode ser uma imposição do próprio ordenamento constitucional. ${ }^{161}$

A declaração de inconstitucionalidade sem a pronúncia de nulidade ocorrerá nos casos em que a aplicação da lei seja indispensável ao período que antecede a promulgação de nova lei, dessa vez constitucional. Isso, pois nesses casos a suspensão da aplicação da norma inconstitucional agravaria o estado de

\footnotetext{
${ }^{160}$ MENDES, Gilmar Ferreira. Op. cit., p. 1373.
} 
inconstitucionalidade, por não haver norma que a substitua.

Um exemplo é o inciso IV do art. 7 da CRFB/88 que dispõe sobre o salário mínimo e exige, expressamente, norma regulamentadora. Ocorre que a lei que estabelece o salário mínimo padece do vício de inconstitucionalidade por omissão parcial, por ser insuficiente e não corresponder as exigências do constituinte. Entretanto, declarar sua nulidade significaria que o salário mínimo ficaria sem regulamentação, a mercê da discricionariedade dos empregadores.

Assim, faz-se necessária uma análise, com base no princípio da proporcionalidade, confrontando os interesses afetados pela norma inconstitucional e aqueles possivelmente sacrificados em consequência da declaração de nulidade.

$\mathrm{O}$ art. 27 da Lei 9.868/99 traz alternativas à regra da retroatividade da declaração de inconstitucionalidade pela via principal, já largamente utilizadas pela jurisprudência da Corte Constitucional. A primeira possibilidade é a lei ser eliminada do ordenamento jurídico a partir do trânsito em julgado da decisão (efeitos ex nunc). A segunda é a lei ser eliminada a partir de determinado momento futuro (efeitos pro futuro). A terceira possibilidade que se abre é justamente a declaração de inconstitucionalidade sem pronúncia de nulidade, ou seja, sem que haja a suspensão da lei. ${ }^{162}$

\footnotetext{
${ }^{161}$ MENDES, Gilmar Ferreira. Op. cit., p. 1384.

${ }^{162}$ MENDES, Gilmar Ferreira. Op. cit., p. 1386-1387.
} 


\section{Conclusão}

O presente trabalho, que tem por objeto a análise dos efeitos das declarações de inconstitucionalidade em Ações Diretas, procurou introduzir os leitores ao tema por meio do estudo do controle de constitucionalidade, que acabou desaguando no atual modelo de fiscalização que, apesar de jurisdicional misto, viu o controle concentrado ganhar destaque desde a Constituição da República de 1988.

São diversos os motivos que levaram à expansão do controle de constitucionalidade que, como se sabe, ocorre via ação direta. Primeiramente , há de se destacar o aumento no rol de legitimados para a propositura da Ação Direta de Inconstitucionalidade, antes monopólio do Procurador Geral da República. A CRFB/88 ampliou a legitimidade para ADI a outros agentes e órgãos, o que facilitou e aumentou a fiscalização das leis via ação direta.

Além disso, o próprio controle concentrado se expandiu com a criação de outras Ações Diretas. Na Carta Magna de 1988 foram previstas, além da ADI, mais três ações, sendo duas delas novas: a Ação Direta de Inconstitucionalidade por Omissão e a Arguição de Descumprimento de Preceito Fundamental - esta última prevista na Carta e regulamentada pela Lei no. 9.882/99. Pouco depois, a Emenda Constitucional no. 3 de 1993 criou a Ação Declaratória de Constitucionalidade. A Ação Declaratória de Constitucionalidade que, a princípio, tinha seu rol de legitimados restrito a quatro órgãos, passou, com a EC 45/2004 a ter os mesmos legitimados da ADI e da ADO.

A essas razões, não podemos esquecer de adicionar a promulgação da Lei 9.868 de 1999, que regulamentou o processo e o julgamento da ADI, da ADC e da $\mathrm{ADO}$ e inovou no controle concentrado brasileiro. Uma das inúmeras novidades trazidas pela lei que, na verdade, já era prática jurisprudencial da Corte Constitucional, foi a possibilidade de modulação dos 
efeitos das decisões de inconstitucionalidade em Ações Diretas.

O sistema brasileiro de constitucionalidade, ao adotar a Teoria da Nulidade da norma inconstitucional, entendeu que a norma incompatível com a Constituição é inválida, portanto, ineficaz, e que esse vício é congênito ao seu ingresso na ordem jurídica. Sendo assim, a declaração de inconstitucionalidade deve retroagir ao nascimento da norma, ou seja, ter efeitos ex tunc.

Algumas situações práticas, entretanto, exigiram uma posição menos radical a respeito dos efeitos temporais da decisão. Assim foi feito pela jurisprudência e ratificado pela legislação, na Lei 9.868/99, em seu art. 27, que previu a possibilidade de efeitos ex nunc ou mesmo pró futuro. Estudamos cada uma das possibilidades de modulação de efeitos nas decisões de inconstitucionalidade.

Em relação aos demais efeitos da declaração de inconstitucionalidade em Ações Diretas não encontramos muitas divergências. O efeito subjetivo, em consequência da legitimidade extraordinária, é erga omnes e vinculante, ou seja, vale para todos e vincula os órgãos judiciais e a Administração Pública. Mencionamos também a possibilidade de haver o efeito transcendente na decisão do Supremo, que estende a força vinculante da decisão, passando a abranger não só a parte dispositiva mas também os fundamentos.

Quanto ao efeito objetivo, falamos na declaração de invalidade da norma e, consequentemente, de sua ineficácia. Constatamos que não há um ato que retire formalmente a norma do ordenamento jurídico, mas na prática é como se houvesse, pois a norma perde a sua vigência. Outro efeito objetivo estudado foi o repristinatório, que restaura a vigência da norma revogada pela norma inconstitucional, mas que pode ser afastado expressamente na decisão do STF.

"Os efeitos das decisões de inconstitucionalidade em Ações Diretas" é um tema atual e de extrema importância, visto a expansão quantitativa e qualitativa do controle concentrado e a evolução da sociedade, que exige a 
constante atualização do direto para a resolução das questões práticas, mesmo em se tratando da análise da lei em tese que, desvinculada de lide ou de partes, importa e atinge toda a coletividade. 


\section{Bibliografia}

BARROSO, Luís Roberto. O Controle de Constitucionalidade no Direito Brasileiro: exposição sistemática da doutrina e análise crítica da jurisprudência . $6^{\text {a }}$ ed. rev. e atual. São Paulo: Saraiva, 2012.

CAPPELLETTI, Mauro. O Controle Judicial de Constitucionalidade das Leis no Direito Comparado. Porto Alegre: S.A. Fabris, 1985

CLÈVE, Clèmerson Merlin. A Fiscalização Abstrata da Constitucionalidade no Direito Brasileiro. São Paulo: Revista dos Tribunais, 1995.

Constituição da República Federativa do Brasil de 1988.

CUNHA Jr., Dirley da. O Controle de Constitucionalidade na França e as alterações advindas da Reforma Constitucional de 23 de julho de 2008.

HAMILTON, Alexander. The Federalist no. 78. Independent Journal. Disponível em <http://www.constitucion.org/fed/federa78.htm>. Acesso em 20 out. 2014.

KELSEN, Hans. Teoria Pura do Direito. $6^{\text {a }}$ ed. São Paulo: Martins Fontes, 1998.

Lei $\mathrm{n}^{\circ} 9.868$ de 10 de novembro de 1999

LENZA, Pedro. Direito Constitucional Esquematizado. $15^{\mathrm{a}}$ ed. rev., atual e ampl. São Paulo: Saraiva, 2011. 
MENDES, Gilmar Ferreira. Curso de Direito Constitucional. $6^{\mathrm{a}}$ ed. rev. e atual. - São Paulo: Saraiva, 2011.

POLETTI, Ronaldo. Controle da Constitucionalidade das Leis. Rio de Janeiro: Forense, 1995.

SILVA, José Afonso da. Curso de Direito Constitucional Positivo. $36^{\text {a }}$ ed. São Paulo: Malheiros, 2013.

STF, ADI n 2895/AL, rel. Ministro Carlos Veloso, Alagoas, 2 de fevereiro de 2005.

STF, ADI no 2995/PE, rel. Ministro Celso de Mello, Pernambuco, 13 de dezembro de 2006.

STF, ADI no 3323/DF, rel. Ministro Joaquim Barbosa, Distrito Federal, 9 de março de 2005.

STF, ADI n ${ }^{\circ}$ 652/MA, rel. Ministro Celso de Mello, Maranhão, 2 de abril de 1992.

STF, Rp: 1379/MG, rel. Ministro Moreira Alves, Minas Gerais, 12 de agosto de 1987.

ZAVASCKI, Teori Albino. Eficácia das Sentenças na Jurisdição Constitucional. $3^{\text {a }}$ ed. rev., atual. e ampl. São Paulo: Editora Revista dos Tribunais, 2014, 